\title{
Michał Comporek*
}

\section{KSZTAŁTOWANIE STANDINGU FINANSOWEGO KLUBÓW PILKARSKICH NOTOWANYCH NA STOXX EUROPE FOOTBALL INDEX W LATACH 2007-2011 W ZALEŻNOŚCI OD OSIĄGANYCH PRZEZ NIE REZULTATÓW SPORTOWYCH}

\section{WPROWADZENIE}

We współczesnym świecie sport ${ }^{1}$ jest bezcenną wartością cywilizacyjną, kulturową i społeczną. W rozwiniętych społeczeństwach jest on postrzegany jako dobro powszechne, dostępne w różnych formach - stosownie do możliwości i zainteresowań obywateli. Niepowtarzalny wymiar sportu wynika nie tylko z możliwości jego oddziaływania na kondycję fizyczną człowieka, ale także z pozytywnego wpływu na ludzką psychikę - poprzez pobudzanie takich idei, jak: duch współzawodnictwa, tolerancja i poszanowanie drugiej osoby, fair play itp. W ten sposób przyczynia się on do indywidualnego rozwoju oraz samorealizacji jego uczestników².

Sport jest także składową polityki społecznej nowoczesnego państwa, stymulując wiele gałęzi gospodarki ${ }^{3}$. Może on służyć za narzędzie rozwoju lokalnego i regionalnego, przyczyniać się do tworzenia nowych miejsc pracy, wpływać na poprawę infrastruktury technicznej obszaru itp. „Rachunek Satelitarny Sportu dla Polski”, stworzony przez Instytut Statystyki Publicznej GUS w 2010 r.

\footnotetext{
* Mgr, Katedra Analizy i Strategii Przedsiębiorstwa, Wydział Ekonomiczno-Socjologiczny Uniwersytetu Łódzkiego, Łódź 90-214, ul. Rewolucji 1905 r. nr 41.

${ }^{1} \mathrm{~W}$ powszechnym znaczeniu sport rozumiany jest jako ,wszelkie formy aktywności fizycznej, które poprzez uczestnictwo doraźne lub zorganizowane, stawiają sobie za cel wypracowanie lub poprawienie kondycji fizycznej lub psychicznej, rozwój stosunków społecznych lub osiągnięcie wyników sportowych na wszelkich poziomach" (Biała Księga na Temat Sportu, Komisja Wspólnot Europejskich, Bruksela 2007, s. 2).

${ }^{2}$ Biała Księga..., op. cit., s. 3.

${ }^{3}$ Strategia rozwoju sportu w Polsce do roku 2015 (zaktualizowana wersja Strategii rozwoju sportu do roku 2012 - cele i zadania, przyjętej przez Radę Ministrów 11 lutego 2003 r.), Ministerstwo Sportu, Warszawa 2007, s. 4.
} 
zakłada, że wartość całkowita popytu w naszym kraju na dobra i usługi sportu wyniosła w 2006 r. 20,7 mld zt ${ }^{4}$. W ujęciu względnym było to równoważne udziałowi PKB sportu w całkowitym PKB Polski na poziomie $1,96 \%{ }^{5}$. Z kolei w całej Unii Europejskiej w tym samym czasie sport w szerszym znaczeniu wytworzył aż 3,7\% PKB i zagwarantował miejsce pracy dla blisko 5,4\% siły roboczej Wspólnoty.

Zdaniem Międzynarodowej Federacji Piłki Nożnej (FIFA) piłkę nożną zawodowo uprawia około 270 mln zawodników oraz zawodniczek, którzy są zrzeszeni w blisko 500 tys. klubów piłkarskich ${ }^{6}$.

Analizując historię futbolu okazuje się, że w większości przypadków kluby piłkarskie powołane zostały przez lokalne społeczności, w których odgrywały i do tej pory odgrywają bardzo ważną rolę. ${ }^{7}$. Tacon jest zadania, że klub piłkarski traktować można jako swoistą instytucję reprezentującą dany region i budującą lokalną tożsamość ${ }^{8}$. Z perspektywy kibiców, klub piłkarski był i pozostanie instytucją społeczną, kulturową, a nie rynkowym przedsiębiorstwem ${ }^{9}$. Trzeba jednak pamiętać, że w branży piłkarskiej występuje wielu ,aktorów”, spośród których każdy ma swoje własne interesy i zapatrywania (zob. tab. 1).

Wydaje się jednak, że obecne funkcjonujące kluby piłkarskie są podobne jak nigdy dotąd do typowych przedsiębiorstw produkcyjnych bądź usługowych, nastawionych na generowanie zysku. Są one bowiem w stanie samodzielnie pozyskiwać i wydatkować środki pieniężne w oparciu o swoją działalność. Jedyną różnicą jest charakter branży, w której działają. Autorzy opracowań dotyczących tematyki biznesu w sporcie, tacy jak: M. Mosiądz i F. Roy, są zdania, że klub sportowy możemy po prostu traktować jak przedsiębiorstwo działające w specyficznej branży o bardzo wysokim ryzyku działalności, które wynika $\mathrm{z}$ uzależnienia przychodów klubu od uzyskanego wyniku sportowego ${ }^{10}$.

${ }^{4}$ Rachunek satelitarny sportu dla Polski, Instytut Statystyki Publicznej Głównego Urzędu Statystycznego, Warszawa 2010, s. 28.

5 Jako podstawa niniejszych obliczeń zastosowana została tzw. „szeroka definicja sportu” uwzględniona w tzw. Definicji wileńskiej sportu. Szeroka definicja sportu obejmuje wszystkie istotne gałęzie przemysłu i rodzaje działalności bezpośrednio lub pośrednio związane ze sportem, dla których sport jest istotnym wkładem w ich funkcjonowanie (np. transmisje telewizyjne, produkcja gier komputerowych). Szerzej w: Rachunek satelitarny..., s. 11-12.

6 Wyjaśnienie istoty „klubu sportowego” oraz „klubu piłkarskiego” znajduje się w dalszej części artykułu.

${ }^{7}$ Ł. Tusiński, Trzy podstawowe funkcje $w$ działalności klubów piłkarskich, $\mathrm{http} / / / \mathrm{www} \cdot$ marketingsportowy.pl/index.php?option=com_content\&task=view\&id=346.

${ }^{8}$ R. T a co n, Football and Social Inclusion: Evaluating Social Policy, Football Governance Research Center, Research Paper 2005 No. 1.

${ }^{9}$ Ł. Tusiński, op. cit.

${ }^{10}$ M. Mosiądz, F. Roy, Klub sportowy a przedsiębiorstwo - podejście do wyceny, Fitz Roy Conculting \& Investments, http://fitz-roy.pl/BAZA-WIEDZY/Klub-sportowy-a-przedsiebiorstwo-podejscie-do-wyceny. 
Zróżnicowanie interesów poszczególnych „aktorów” piłkarskiego biznesu

\begin{tabular}{|l|l|c|c|}
\hline \multicolumn{1}{|c|}{ Aktorzy } & \multicolumn{1}{|c|}{ Główne interesy } & $\begin{array}{c}\text { Znaczenie kwestii } \\
\text { sportowych }\end{array}$ & $\begin{array}{c}\text { Znaczenie kwestii } \\
\text { biznesowych }\end{array}$ \\
\hline Kluby & Odnoszenie sukcesów sportowych & +++ & ++ \\
\hline Związki & $\begin{array}{l}\text { Zabezpieczenie gry (formalne, prawne, } \\
\text { logistyczne itp.); podkreślanie znacze- } \\
\text { nia piłki nożnej jako dyscypliny spor- } \\
\text { towej }\end{array}$ & +++ & ++ \\
\hline Piłkarze & $\begin{array}{l}\text { Gra na jak najwyższym poziomie; jak } \\
\text { najwyższe zarobki }\end{array}$ & +++ & ++ \\
\hline Rząd & $\begin{array}{l}\text { Ochrona i podkreślanie wartości spo- } \\
\text { łecznych i kulturowych piłki nożnej }\end{array}$ & ++ & +++ \\
\hline Sponsorzy & $\begin{array}{l}\text { Czerpanie finansowych korzyści } \\
\text { i profitów płynących ze sponsorowania }\end{array}$ & ++ & + \\
\hline Kibice & $\begin{array}{l}\text { Bycie czę́sią sportowej wspólnoty; } \\
\text { przezywanie i spełnianie sportowych } \\
\text { marzeń }\end{array}$ & +++ \\
\hline
\end{tabular}

Źródło: opracowanie własne na podstawie: A. B uhler, Football as an international business - an Anglo-German comparison, „European Journal for Sport and Society” 2006, Vol. 3(1), Plymouth 2006, s. 33.

Osobliwy charakter rynku oraz produktu oferowanego przez kluby sportowe poruszyli także S. Hamil, J. Michie, C. Oughton, którzy w swojej publikacji nawiązali do fragmentu klasycznej analizy biznesu sportowego Rothenberga:

Dwie grajace ze sobq drużyny sq jak dwie firmy wytwarzajace jeden produkt. $\mathrm{Na}$ produkt finalny składa się gra (widowisko sportowe), jak również ludzie zebrani na trybunach. Przy określonej opłacie za wstęp na stadion, produktem jest widowisko sportowe powiększone o liczbę kibiców, którzy zapłacili za bilety. Jeżeli na trybunach jest 30000 osób wynik finalny jest dwukrotnie większy niż przy piętnastotysięcznej frekwencji. W tej samej chwili, w jednym sensie drużyny ze soba konkuruja, a z drugiej strony współtworza jedno przedsięwzięcie, którego sukces jest tym większy, o ile różnice pomiędzy poziomem sportowym zespołów sq mniejsze $e^{11}$.

Zasadniczym celem artykułu jest weryfikacja hipotezy stwierdzającej, że standing finansowy klubów piłkarskich notowanych na Stoxx Europe Football Index w latach 2007-2011 jest w bardzo dużym stopniu uzależniony od osiaga-

${ }^{11}$ Ł. Tu siński, op. cit., [za:] S. Ha mil, J. Michie, C. Oughton (red.), A Game of Two Halves? The Business of Football, Edynburg 1999. 
nego przez nie wyniku sportowego. Weryfikacji empirycznej powyższej hipotezy towarzyszy następujące pytanie badawcze: czy dążenie klubów piłkarskich działających w formie sportowych spółek akcyjnych do osiagania jak największej liczby sukcesów sportowych motywowane jest wyłącznie przesłankami finansowymi?

Postawiona hipoteza badawcza poddana została weryfikacji empirycznej z wykorzystaniem wybranych miar oceny efektywności finansowej przedsiębiorstwa. Należą do nich:

- współczynnik ogólnego zadłużenia (wraz z dynamiką jego zmian),

- współczynnik pokrycia zobowiązań nadwyżką finansową,

- współczynnik rentowności netto,

- wskaźnik dynamiki sprzedaży.

Analiza korelacji zachodzących pomiędzy zastosowanymi miarami standingu finansowego klubów piłkarskich (które pozwoliły dokonać wstępnej oceny klubów z ich perspektywy finansowej), a rezultatami sportowymi uzyskanymi przez badane podmioty stanowi zasadniczą metodę weryfikacji empirycznej postawionej hipotezy badawczej.

\section{KLUB SPORTOWY W UJĘCIU PRAWNYM}

D. Dudek jest zdania, iż nie jest znana geneza oraz prawne aspekty funkcjonowania klubów sportowych ${ }^{12}$. Pierwsze kluby powstały w Anglii w drugiej połowie XVIII w. Łączyły one cele kultury fizycznej z celami towarzyskimi, hobbystycznymi, dyskusyjnymi, wychowawczymi, obywatelskimi, światopoglądowymi oraz politycznymi ${ }^{13}$.

W kontynentalnej części Europy w XVIII i XIX w. kluby nie istniały w ogóle. Ustawodawstwo niemieckie wydzielało w tym czasie dwa typy zrzeszeń: towarzystwa (Verein) - o celach: zawodowych, oświatowych, wychowawczych, naukowych, kulturalnych i towarzyskich, jak również stowarzyszenia (Genossenschaft) - dążące do osiagnięcia bezpośrednich korzyści gospodarczo-zarobkowych $^{14}$. W późniejszych latach w prawodawstwie europejskim pozostało jedynie ,stowarzyszenie”, będące podstawową formułą prawną, na podstawie której zakładano organizacje działające w sferze kultury fizycznej. Ze

${ }^{12}$ D. Dudek, Pojęcie klubu sportowego, „Studia Humanistyczne” 2005, nr 5, Akademia Wychowania Fizycznego w Krakowie, Kraków 2005, s. 17.

${ }^{13}$ Ibidem, s. 24.

${ }^{14}$ D. Du dek, Krytyczne tezy do naukowych badań nad sportem, [w:] T. J u re k, K. Obod y ń s ki, S. Z a bo rn i a k (red.), Z dziejów turystyki i sportu w Polsce, Wydawnictwo Uniwersytetu Rzeszowskiego, Rzeszów 2009, s. 287-305. 
względu na rozwój nowożytnego sportu na europejską formułę prawną stowarzyszenia nałożono zwyczajową nazwę angielskiego klubu sportowego ${ }^{15}$.

W Polsce po raz pierwszy pojęcie klubu sportowego pojawiło się w związku z uchwaleniem Ustawy z dnia 18 stycznia 1996 r. o kulturze fizycznej (DzU 1996, nr 25, poz. 113). Ustawa to określała klub sportowy jako: ,podstawową jednostkę organizacyjną realizującą cele i zadania w zakresie kultury fizycznej". Zdaniem badaczy pod względem legislacyjnym było to sformułowanie błędne. D. Dudek jest zdania, że klub sportowy nie jest podmiotem prawa. Jest to jedynie zwyczajowa nazwa pewnej organizacyjnej formuły dopuszczonej prawem ${ }^{16}$. Może on funkcjonować jako:

- stowarzyszenie,

- stowarzyszenie kultury fizycznej,

- uczniowski klub sportowy,

- sportowa spółka akcyjna,

- inna forma organizacyjna uwzględniona w polskim prawie.

Ustawa stanowi przy tym, że klub sportowy „może działać jako osoba prawna utworzona na podstawie odrębnych przepisów albo jako osoba fizyczna będąca przedsiębiorcą w rozumieniu przepisów Ustawy z dnia 2 lipca 2004 r. o swobodzie działalności gospodarczej (DzU 2004, nr 173, poz. 1807)".

Przedstawione informacje wyraźnie ukazują, że pojęcie klubu sportowego jest niezwykle szerokie i ma ono bardziej wymiar potoczny (funkcjonujący w języku pisanym i mowie codziennej), aniżeli prawny. W niniejszym artykule pojawia się również sformułowanie ,klub piłkarski”. W literaturze przedmiotu nie występuje definicja „klubu piłkarskiego”. Zdaniem autora jest to po prostu klub sportowy, który bierze udział w szeroko rozumianych rozgrywkach piłkarskich. Należy przy tym podkreślić, iż niejednokrotnie kluby piłkarskie stanowią jedynie część (sekcję) klubu sportowego.

\section{ISTOTA WARTOŚĆI KLUBU PILKARSKIEGO}

Na wartość klubu piłkarskiego wpływ ma szereg determinant ${ }^{17}$. Oprócz czynników typowych dla większości przedsiębiorstw (takich jak: sposób wykorzystania aktywów, sposób zarządzania, potencjał wzrostu, przychody i koszty

\section{${ }^{15}$ Ibidem.}

${ }^{16}$ D. Dudek, Zarys dziejów $i$ organizacja stowarzyszeń kultury fizycznej, „Studia i Monografie" 2000, nr 16, Akademia Wychowania Fizycznego w Krakowie, Kraków 2000, s. 105.

${ }^{17}$ Wartość firmy to suma wartości materialnych i niematerialnych, gdzie wartości materialne to posiadany przez firmę majątek, czyli wszystkie aktywa ewidencjonowane w bilansie pomniejszone o zobowiązania, a wartości niematerialne to nadwyżka wartości rynkowej składników firmy (W. Gru d zew s ki, I. Hej d u k, Restrukturyzacja firmy jako kierunek wzrostu jej wartości, [w:] A. Herman, A. Szablewski (red.), Zarzqdzanie wartościq firmy, Wydawnictwo Poltext, Warszawa 1999, s. 200-201). 
płynące z działalności operacyjnej itd.), wyróżnić można takie determinanty, które są charakterystyczne dla podmiotów działających na rynku sportowym. Do najważniejszych z nich zaliczyć należy:

- sukcesy sportowe (zarówno te osiagnięte w przeszłości, obecne, jak i te oczekiwane w przyszłości),

- piłkarzy oraz sztab szkoleniowy,

- sponsorów strategicznych,

- liczbę kibiców,

- markę klubu ${ }^{18}$.

Zdaniem autora współczesne profesjonalne kluby piłkarskie działające w formie sportowych spółek akcyjnych powinny być w stanie samodzielnie pozyskiwać środki pieniężne w oparciu o swoją działalność. Jednocześnie ich zdolność do generowania gotówki jest w ogromnej mierze uzależniona od osiąganych rezultatów sportowych. Satysfakcjonujące wyniki sportowe przekładają się bowiem na uzyskiwane przez kluby wpływy: ze sprzedaży biletów, reklam oraz praw do transmisji meczów.

Oczywiście osiagane rezultaty sportowe mają wpływ na liczbę kibiców, których dany klub posiada. $Z$ punktu widzenia organizacji to właśnie kibic-klient stanowi najcenniejsze źródło tworzenia wartości przedsiębiorstwa. Jest on „najcenniejszy”, ponieważ generuje przychody, niezbędne do egzystencji i rozwoju przedsiębiorstwa oraz tworzy warunki dla bezpiecznego obrotu i wzrostu gospodarczego $^{19}$. Największe kluby piłkarskie świata posiadają rzesze swoich stałych sympatyków, którzy poprzez szeroko pojmowane kibicowanie (zakup biletów gwarantujących uczestnictwo w imprezach sportowych z ich udziałem, nabywanie pamiątek sportowych itp.) aktywnie uczestniczą w ich ekonomicznym funkcjonowaniu. W 2010 r. aż 57,8 mln kibiców z całego świata zadeklarowało, że ich ulubionym klubem piłkarskim jest F.C. Barcelona. Na kolejnych miejscach znalazły się natomiast: Real Madryt (31,3 mln kibiców) oraz Manchester United $(30,5 \text { mln kibiców })^{20}$. Dane te wyraźnie pokazują, że piłka nożna na przestrzeni ostatnich lat przeistoczyła się w wielki biznes skupiający uwagę milionów ludzi.

Według globalnego rankingu klubów piłkarskich Football Money League przygotowanego przez firmę doradczą Deloitte, łączne przychody największych dwudziestu klubów piłkarskich świata wzrosły w sezonie 2010/2012 o 3\% w porównaniu z wcześniejszym sezonem (zob. tab. 2). Ich stopa wzrostu dwukrotnie przekroczyła tempo rozwoju gospodarek, które reprezentują, zaś łączne

18 M. Głodowski, Wycena klubu pitkarskiego na przyktadzie Juventus Turyn, [w:] M. Panfil, A. Szablewski (red.), Wycena przedsiębiorstwa. Od teorii do praktyki, Wydawnictwo Poltex, Warszawa 2010, s. 612.

${ }_{19}$ W. Skoczylas (red.), Determinanty $i$ modele wartości przedsiębiorstw, Polskie Wydawnictwo Ekonomiczne, Warszawa 2007, s. 206.

${ }^{20}$ Informacje zaczerpnięte z portalu www.sportundmarkt.de. 
przychody przekroczyły kwotę 4,4 mld euro ${ }^{21}$. Należy przy tym podkreślić, że dane w momencie sporządzania raportu nie były oficjalnie potwierdzone (przed dokonaniem analizy Deloitte nie przeprowadził weryfikacji ani audytu informacji zawartych w sprawozdaniach finansowych i innych źródłach stanowiących podstawę publikacji). Wykazywane przychody nie uwzględniają opłat z tytułu transferu zawodników, podatku VAT oraz podatku obrotowego ${ }^{22}$.

Tabela 2

Najbogatsze kluby piłkarskie świata według Deloitte w 2011 r. (kwoty podane w mln euro)

\begin{tabular}{|c|c|c|c|c|}
\hline Lp. & Klub piłkarski & Kraj & $\begin{array}{c}\text { Przychody w sezonie } \\
2009 / 2010\end{array}$ & $\begin{array}{c}\text { Przychody w sezonie } \\
2010 / 2011\end{array}$ \\
\hline 1 & Real Madryt & Hiszpania & 438,6 & 479,5 \\
\hline 2 & FC Barcelona & Hiszpania & 398,1 & 450,7 \\
\hline 3 & Manchester United & Anglia & 349,8 & 367,0 \\
\hline 4 & $\begin{array}{c}\text { Bayern } \\
\text { Monachium }\end{array}$ & Niemcy & 323,0 & 321,4 \\
\hline 5 & Arsenal & Anglia & 274,1 & 251,1 \\
\hline 6 & Chelsea & Anglia & 255,9 & 249,8 \\
\hline 7 & AC Milan & Włochy & 244,0 & 235,1 \\
\hline 8 & Internazionale & Włochy & 224,8 & 211,4 \\
\hline 9 & Liverpool & Anglia & 225,3 & 203,3 \\
\hline 10 & Schalke 04 & Niemcy & 139,8 & 202,4 \\
\hline 11 & $\begin{array}{c}\text { Tottenham } \\
\text { Hotspur }\end{array}$ & Anglia & 146,3 & 181,0 \\
\hline 12 & Manchester City & Anglia & 152,8 & 169,6 \\
\hline 13 & Juventus & Włochy & 205,0 & 153,9 \\
\hline 14 & $\begin{array}{l}\text { Olympique de } \\
\text { Marseille }\end{array}$ & Francja & 141,1 & 150,4 \\
\hline 15 & AS Roma & Włochy & 122,7 & 143,5 \\
\hline 16 & $\begin{array}{c}\text { Borussia } \\
\text { Dortmund }\end{array}$ & Niemcy & 105,2 & 138,5 \\
\hline 17 & $\begin{array}{l}\text { Olympique } \\
\text { Lyonnais }\end{array}$ & Francja & 146,1 & 132,8 \\
\hline 18 & Hamburger SV & Niemcy & 146,2 & 128,8 \\
\hline 19 & Valencia & Hiszpania & 99,3 & 116,8 \\
\hline 20 & SSC Napoli & Włochy & 91,6 & 114,9 \\
\hline
\end{tabular}

Źródło: opracowanie własne na podstawie Deloitte Football Money League 2012.

${ }^{21}$ Informacje zaczerpnięte $\mathrm{z}$ portalu:

http://www.deloitte.com/view/pl_PL/pl/branze/sport/3e90b369f5d55310VgnVCM3000001c56f00 aRCRD.htm.

${ }^{22}$ Więcej informacji o metodologii badań można znaleźć na portalu internetowym Deloitte http://www.deloitte.com/view/pl_PL/pl/branze/sport/3e90b369f5d55310VgnVCM3000001c56f00 aRCRD.htm. 


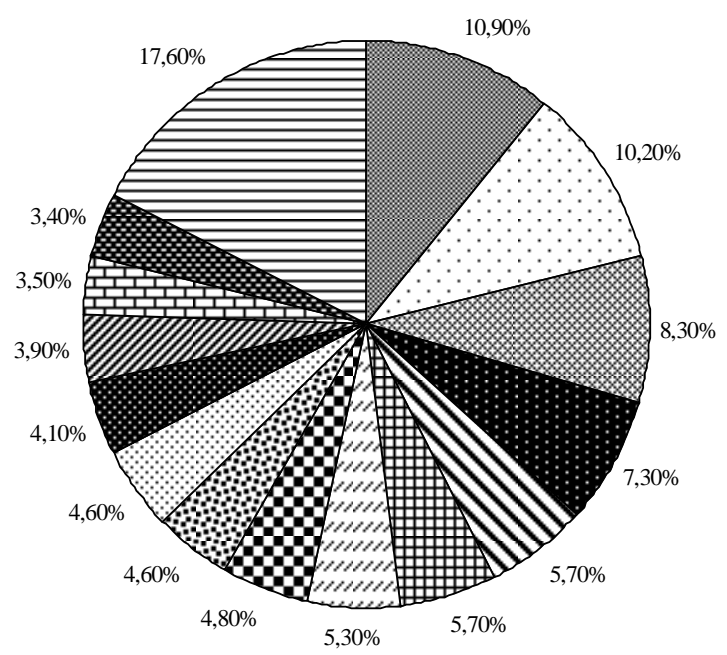

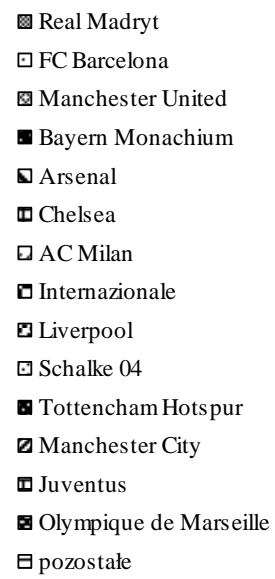

Rys. 1. Udział wybranych klubów piłkarskich w zestawieniu najbogatszych klubów piłkarskich świata według Deloitte w $2011 \mathrm{r}$.

Źródło: opracowanie własne na podstawie Deloitte Football Money League 2012.

Dane przedstawione w tab. 2 oraz rys.1 wyraźnie sugerują, że największe przychody generują kluby piłkarskie z Hiszpanii, Anglii i Włoch oraz (w nieco mniejszym zakresie) z Niemiec i Francji. Pojawia się jednak pytanie, w jaki sposób należy odczytywać te informacje? Wystarczy wspomnieć, że długi wszystkich hiszpańskich klubów piłkarskich na chwilę obecną szacowane są na kwotę 4 mld euro (w tym 752 mln euro względem Skarbu Państwa). Łączne długi Realu Madryt i FC Barcelony, a więc klubów mających największe przychody, wynoszą ponad $750 \mathrm{mln}$ euro. Oczywiście, są one w stanie w trakcie sezonu wygenerować wpływy, które starczają na spłacanie rat, funkcjonowanie klubu i utrzymanie infrastruktury. Są one często wspomagane przez banki, które pomagają $\mathrm{w}$ transferach, ponieważ uważają, że dochody ich kredytobiorcy nie spadną nigdy poniżej pewnego określonego poziomu ${ }^{23}$. Jednak pozostała część klubów piłkarskich w Hiszpanii balansuje na skraju bankructwa. Wiele klubów skorzystało z tzw. „Ley Concursal”, tj. prawa, które umożliwia przesunięcie spłaty długu w czasie bez konieczności ogłoszenia bankructwa ${ }^{24}$. We Włoszech w 2012 roku zadłużenie najwyższej ligi włoskiej Serie A wzrosło o 14\% do kwoty 2,6 mld euro. Na 107 wszystkich klubów piłkarskich tylko 19 odnotowało

${ }^{23}$ Więcej informacji na stronie internetowej www.transfery.info/51673,dlugi-zniszcza-pilkarska-europe-hiszpania.

${ }^{24}$ Więcej informacji na stronie internetowej http://sport.onet.pl/pilka-nozna/liga-hiszpanska/ primera-division-ogromne-dlugi-pilkarze-nie-otrzym,1,4655162, wiadomosc.html. 
zysk netto. Juventus Turyn, Inter Mediolan oraz A.C. Milan łącznie są zadłużone na kwotę około 800 mln euro ${ }^{25}$. Podobna sytuacja panuje w Anglii.

Na tym polu znacznie lepiej wypadają kluby piłkarskie z Niemiec i Francji. Bayern Monachium w praktyce jest wolny od długu. Borussia Dortmund (której w 2005 r. groziło bankructwo) w 2011 r. wykazała dług wynoszący zaledwie $56 \mathrm{mln}$ euro ${ }^{26}$. Analitycy uważają, że w 2012 r. zostanie on wyraźnie zmniejszony. We Francji z kolei działa instytucja kontrolująca finanse zawodowych klubów piłkarskich (Direction National du Control de Gestion). Istnieje ona od 1984 r. i zasiadają w niej prawnicy, finansiści, księgowi - osoby niezależne od organizatorów francuskiej ligi zawodowej. Podczas przerwy między rozgrywkami kluby są wzywane przez DNCG i muszą przedstawić sprawozdanie finansowe z minionego sezonu oraz przedstawić plan budżetu na kolejny rok rozgrywek. Kluby przynoszące straty są zobowiązane do ich pokrycia. Jeżeli nie są w stanie uregulować zadłużenia, to nakładane są na nie sankcje, takie jak: zakaz przeprowadzania transferów, kontrola wydatków, karna degradacja (spotkała ona $\mathrm{m}$. in. uznane drużyny piłkarskie, takie jak: Bordeaux czy Strasburg) ${ }^{27}$. W czasie trwającego kryzysu gospodarczego wiele piłkarskich klubów we Francji zaczyna popadać w zadłużenie. Jest ono jednak niewspółmiernie niższe aniżeli zadłużenie klubów angielskich, hiszpańskich i włoskich.

Celem artykułu nie jest dokonywanie teoretycznych rozważań nad możliwościami oszacowania wartości klubu piłkarskiego (zwłaszcza jego aktywów). Intencją autora jest jedynie zasygnalizowanie, że precyzyjne dokonanie takiej wyceny jest zadaniem dość skomplikowanym. W literaturze przedmiotu spotkać się można ze stwierdzeniami, że do chwili obecnej nie znaleziono jednej (dobrej) metody służącej do kalkulowania wartości przedsiębiorstw sportowych. Trudności z odpowiednim dokonaniem takiej wyceny mogą przyczynić się $\mathrm{z}$ kolei do pewnych problemów z określaniem standingu finansowego badanych klubów.

Podejmując kwestię wartości klubu piłkarskiego należy wspomnieć o istotnym problemie związanym $\mathrm{z}$ metodologia jej przeprowadzania. Popularna w dziedzinie finansów przedsiębiorstw metoda wyceny za pomocą zdyskontowanych przepływów pieniężnych wydaje się być nieodpowiednia dla klubów piłkarskich, ponieważ występuje wysoka niepewność co do osiągnięcia przychodów z tytułu transferów zawodników oraz przychodów z tytułu sukcesów drużyny na arenie krajowej i międzynarodowej ${ }^{28}$. Analizując historię futbolu bardzo łatwo zauważyć, że niejednokrotnie wysokie wydatki za zakup zawodników w żadnym stopniu nie wpłynęły na osiagane przez klub wyniki sportowe.

\footnotetext{
${ }^{25}$ Raport Calcio 2012, Federcalcio FIGC, Rzym 2012

${ }^{26}$ Więcej informacji na stronie internetowej http://sportplus.dbv.pl/viewpage.php?page_id=68.

${ }^{27}$ Więcej informacji na stronie internetowej http://sportcom.pl/aktualnosci/czytaj/problemyfinansowe-klubow-ligue-1-i-nie-tylko/.

${ }^{28}$ M. Głodow ski, op. cit.
} 
Dlatego też, do wyceny klubów piłkarskich stosować można dwie inne metody, a mianowicie:

- metodę mnożnikową (przy użyciu takich wskaźników jak: cena/sprzedaż - P/S, a także wartość przedsiębiorstwa/zysk operacyjny przed opodatkowaniem, potrąceniem odsetek, deprecjacją i amortyzacją - EV/EBITDA),

- metodę porównawczą (w tym przypadku bardzo ważny jest wybór odpowiednich - podobnych do siebie - klubów piłkarskich $)^{29}$.

Określając wartość rynkową przedsiębiorstwa sportowego najwięcej problemów można napotkać podczas dokonywania wyceny jego marki, a przede wszystkim podczas wyceny praw do rejestracji piłkarzy i sztabu szkoleniowego.

Klub decydując się na ,zakup” nowego piłkarza zazwyczaj jest zobowiązany do zapłaty określonej kwoty pieniędzy na rzecz poprzedniego klubu piłkarza za umożliwienie jego „odsprzedaży”. Od momentu podpisania umowy transferowej zawodnik, a dokładnie prawo do jego karty zawodniczej staje się elementem majątku (aktywów) klubu. Jak mówi ustawa z Ustawa o rachunkowości (DzU 1994, nr 121, poz. 591) wartościami niematerialnymi i prawnymi są nabyte przez jednostkę, zaliczane do aktywów trwałych, prawa majątkowe nadające się do gospodarczego wykorzystania, o przewidywanym okresie ekonomicznej użyteczności dłuższym aniżeli rok, przeznaczone do używania na potrzeby jednostki, a w szczególności autorskie prawa majątkowe, prawa pokrewne, licencje, koncesje, prawa do wynalazków, patentów, znaków towarowych, wzorów użytkowych oraz zdobniczych oraz know-how. Natomiast według MSR 38 wartości niematerialne uważane są za nieposiadające postaci fizycznej niepieniężne składniki aktywów, które są możliwe do zidentyfikowania. Muszą one pozostawać pod kontrolą jednostki i zgodnie z przewidywaniami powinny w przyszłości przynosić korzyści ekonomiczne.

Biorąc pod uwagę powyższe kryteria odnoszące się do wartości niematerialnych wydaje się, że są one spełnione w przypadku praw do kart zawodniczych nabywanych przez kluby. Powoduje to, że należy je ujmować w bilansie jako składnik aktywów tych jednostek. Klub, płacąc określoną kwotę innemu klubowi za danego piłkarza, nabywa jego kartę zawodniczą i uzyskuje prawo do negocjowania $\mathrm{z}$ nim indywidualnego kontraktu ${ }^{30}$.

Zdaniem autora, odpowiednia wycena piłkarza jako aktywa przedsiębiorstwa nie jest kwestią łatwą i jednoznaczną. W chwili przeprowadzania transferu bardzo ciężko jest osądzić, czy wydatkowana na danego zawodnika kwota zwróci się w przyszłości, czy też nie. Nie da się przewidzieć ewentualnych kontuzji piłkarzy, ich zniżek formy itp. Niektóre kluby piłkarskie dokonują odpisów z tytułu utraty wartości kart zawodniczych, jeżeli ich wartość bilansowa jest

${ }^{29}$ Ibidem, s. 616.

${ }^{30} \mathrm{~K}$. M aks y mi u k, Cristiano Ronaldo $w$ sprawozdaniu finansowym, czyli o wartościach niematerialnych $w$ klubach piłkarskich, „BDO Podatki i Rachunkowość” 2008, nr 8(10), www.bdo.pl. 
wyższa od wartości możliwej do uzyskania ${ }^{31}$. Z kolei, jeśli klub piłkarski pozyska piłkarza na zasadzie tzw. wolnego transferu ${ }^{32}$, to jego karta nie podlega wycenie bilansowej. Nie oznacza to przy tym, że pozyskany za darmo zawodnik będzie bezużyteczny. Wręcz przeciwnie - klub będzie mógł w pełni korzystać z jego umiejętności sportowych, a w przyszłości może nawet sprzedać jego kartę za znaczną kwotę pieniędzy.

\section{CHARAKTERYSTYKA SPORTOWYCH SPÓŁEK AKCYJNYCH NOTOWANYCH NA THE STOXX EUROPE FOOTBALL BIORĄCYCH UDZIAL W BADANIU}

Stoxx Europe Football Index jest indeksem giełdowym obejmującym wszystkie kluby piłkarskie, które są notowane na giełdach w kontynentalnej części Europy oraz w Szkocji. Utworzony został przez agencję Dow Jones w 2002 r. Początkowo obejmował 33 podmioty, dziś po 10 latach istnienia skupia 21 klubów piłkarskich, do których należy zaliczyć (w kolejności alfabetycznej): Aalborg BK (Dania), AFC Ajax (Holandia), AIK Sztokholm (Szwecja), Aarhus Elite (Dania), AS Roma (Włochy), Besiktas JK (Turcja), Borussię Dortmund (Niemcy), Broendby IF (Dania), Celtic FC (Szkocja), Fenerbahce SK (Turcja), FC Porto (Portugalia), Galatasaray SK (Turcja), Juventus Turyn (Włochy), Lazio Rzym (Włochy), Olympique Lyon (Francja), Parken Sport \& Entertainment (Dania), Ruch Chorzów (Polska), Silkeborg IF (Dania), SL Benfica (Portugalia), Sporting Lizbona (Portugalia) oraz Trabzonspor Kulubu (Turcja).

Dla celów niniejszego opracowania w próbie badawczej wzięły udział wyłącznie te kluby notowane na Stoxx Europe Football Index, które należą do jednej z dziesięciu najsilniejszych europejskich lig piłkarskich (według rankingu Coutry-Ranking sporządzanego corocznie przez Unię Europejskich Związków Piłkarskich UEFA - tab. 3) ${ }^{33}$. Dzięki temu wyodrębniono te podmioty sportowe, które są bardziej rozpoznawalne i dla których (przy zastosowaniu metody eksperckiej) można było w bardziej obiektywny i rzetelny sposób ocenić osiagnięte w poszczególnych sezonach rezultaty sportowe. Dodatkowo, do badań włączono jedynego polskiego przedstawiciela klubów piłkarskich notowanych na Stoxx Europe Football Index tj. Ruch Chorzów.

\footnotetext{
${ }^{31}$ Ibidem.

${ }^{32}$ Zawodnik nie jest związany kontraktem z żadnym innym klubem i można go pozyskać bez konieczności zapłaty sumy odstępnego.

${ }^{33}$ Country Ranking jest rankingiem mierzącym siłę poszczególnych krajowych lig Europy na podstawie występów drużyn klubowych reprezentujących te ligi w europejskich pucharach (Liga Mistrzów oraz Liga Europy). Za każde zwycięstwo lub remis drużyny klubowej z danego państwa przyznawane są punkty według odpowiedniego sposobu punktowania. Więcej informacji na stronie internetowej www.country-rating.com.
} 
Najsilniejsze piłkarskie ligi Europy według UEFA w sezonie 2012/2013

\begin{tabular}{|c|c|c|}
\hline $\begin{array}{c}\text { Miejsce } \\
\text { w rankingu }\end{array}$ & Kraj & $\begin{array}{c}\text { Kluby reprezentujące daną lige notowane } \\
\text { na Stoxx Europe Football Index }\end{array}$ \\
\hline 1 & Hiszpania & - \\
\hline 2 & Anglia & - \\
\hline 3 & Niemcy & Borussia Dortmund \\
\hline 4 & Włochy & AS Roma, Juventus Turyn, Lazio Rzym \\
\hline 5 & Portugalia & FC Porto, SL Benfica Lizbona, Sporting Lizbona \\
\hline 6 & Francja & Olympique Lyon \\
\hline 7 & Holandia & Ajax Amsterdam \\
\hline 8 & Ukraina & - \\
\hline 9 & Rosja & - \\
\hline 10 & Grecja & Ruch Chorzów \\
\hline$\ldots \mathbf{1 8}$ & Polska & \\
\hline
\end{tabular}

Źródło: opracowanie własne na podstawie Country-Ranking UEFA.

Krótka charakterystyka działalności przyjętych do badań klubów sportowych wskazuje, że:

1. Borussia Dortmund jest klubem mającym na swoim koncie: osiem tytułów mistrzowskich i trzy puchary Niemiec, Puchar Zdobywców Pucharów, Puchar Mistrzów ${ }^{34}$ oraz Puchar Interkontynentalny. W dniu 1 lipca 1999 r. klub Borussia Dortmund został zarejestrowana na giełdzie jako spółka akcyjna Borussia Dortmund $\mathrm{GmbH} \& \mathrm{Co}$.

2. AS Roma jest klubem, który trzykrotnie zdobył mistrzostwo Włoch, dziewięciokrotnie Puchar Włoch, a także jednokrotnie Puchar Miast Targowych. W 1999 r., gdy funkcję prezesa klubu sprawował F.Sensi, AS Romę przekształcono w spółkę akcyjną.

3. Juventus Turyn jest najbardziej utytułowanym klubem we Włoszech. Klub ma na swoim koncie dwadzieścia osiem tytułów mistrza kraju i dziewięć Pucharów Włoch. W rozgrywkach międzynarodowych zespół zwyciężył dwa razy w Pucharze Mistrzów, zdobył jeden Puchar Zdobywców Pucharów, a także trzy Puchary UEFA. Na włoskiej giełdzie Borsa Italiana klub notowany jest od 3 grudnia $2001 \mathrm{r}$.

4. Lazio Rzym powszechnie uważany jest za największy klub sportowy w Europie, ponieważ posiada aż 41 sekcji sportowych. Spośród nich najważniejsze sukcesy odnosiła sekcja piłkarska. Wywalczyła ona dwa tytuły mistrza krajowego, pięć Pucharów Włoch, Puchar Zdobywców Pucharów oraz Superpuchar

${ }^{34}$ Funkcjonująca od 1992 r. Liga Mistrzów traktowana jest jako naturalna następczyni Pucharu Mistrzów i w opracowaniu nie jest wyróżniana oddzielnie. 
Europy. Lazio, jako pierwszy włoski klub piłkarski, przekształcony został w sportową spółkę akcyjną notowaną na giełdzie. Miało to miejsce w $1998 \mathrm{r}$.

5. FC Porto jest jednym z najbardziej utytułowanych klubów piłkarskich w Europie. Dwadzieścia pięć razy wywalczył Mistrzostwo Portugalii, dziewiętnaście razy zdobywał Puchar Portugalii. Ponadto FC Porto dwukrotnie wygrało Puchar Europy, dwukrotnie zdobyło Puchar UEFA oraz święciło triumf w Lidze Europa, jako jedyny zespół portugalski. W 1998 r. klub przekształcono z spółkę akcyjną. Obecnie notowany jest na giełdzie portugalskiej Euronex Lisbon.

6. Benfica Lizbona jest siedmiokrotnym piłkarskim finalistą i dwukrotnym zdobywcą Pucharu Europy, 32-krotnym mistrzem Portugalii i 24-krotnym triumfatorem krajowego pucharu. W 2000 roku utworzono spółkę akcyjną o nazwie Sport Lisboa e Benfica-Futebol SAD, która od maja 2007 roku jest notowana na głównym indeksie giełdowym Euronex Lisbon.

7. Sporting Lizbona to 22-krotny mistrz Portugalii, 14-krotny zdobywca Pucharu Portugalii, jak również zdobywca Pucharu Zdobywców Pucharów. Od 1998 r. sekcja piłkarska klubu funkcjonuje jako spółka akcyjna notowana na giełdzie Euronex Lisbon.

8. Olympique Lyon jest siedmiokrotnym mistrzem Francji oraz pięciokrotnym zdobywcą krajowego Pucharu. Klub nie osiagnął dotychczas spektakularnych sukcesów na arenie międzynarodowej, lecz zaliczany jest do grona największych i najbogatszych klubów piłkarskich w Europie. 8 lutego 2007 r. Olympique Lyon stał się pierwszym francuskim klubem, którego akcje można było kupić w ofercie publicznej. Notowany jest na paryskiej giełdzie.

9. Ajax Amsterdam to 31-krotny zdobywca mistrzostwa Holandii i 18-krotny triumfator Pucharu Holandii. Klub ten odniósł ponadto liczne sukcesy na arenie międzynarodowej: czterokrotnie zdobywał Puchar Mistrzów, trzykrotnie Superpuchar Europy, dwukrotnie Puchar Interkontynentalny, zaś jednokrotnie: Puchar UEFA i Puchar Zdobywców Pucharów. Na amsterdamskim indeksie giełdowym Euronex notowany jest od $1998 \mathrm{r}$.

10. Ruch Chorzów jest (obok Górnika Zabrze) najbardziej utytułowanym klubem piłkarskim w Polsce. Mistrzostwo kraju zdobywał 14-krotnie, trzy razy zdobywał też Puchar Polski. Jako spółka akcyjna Ruch Chorzów został zarejestrowany w 2004 r., zaś 10 grudnia 2008 r., jako pierwszy klub piłkarski w Polsce, zadebiutował na rynku NewConnect ${ }^{35}$.

${ }^{35}$ Przygotowania władz klubu do wejścia na giełdę trwały około roku. Przed debiutem podwyższono kapitał zakładowy poprzez emisję (w ramach subskrypcji prywatnej) 2,8 mln akcji. Około 1,74 mln (akcje serii G po cenie emisyjnej równej 1 zł) nabyli ówcześni główni akcjonariusze klubu - Mariusz Klimek i Dariusz Smagorowicz. Pozostałe akcje, po nominalnej cenie wynoszącej 1,7 zł, trafiły do kolejnych 14 inwestorów. Z ich emisji pozyskano około $1,8 \mathrm{mln}$ zł kapitału. Kurs akcji klubu wzrósł na otwarciu w pierwszym dniu notowań na o 35,29 proc. do kwoty 2,3 zł za akcję. Na przestrzeni lat zauważyć można jednak niekorzystną tendencję polegającą na znacznym spadku wartości akcji Ruchu Chorzów SA. Według stanu na 21.09.2012 r. kurs akcji 


\section{OCENA STANDINGU FINANSOWEGO KLUBÓW PILKARSKICH NOTOWANYCH NA THE STOXX EUROPE FOOTBALL}

Standing finansowy przedsiębiorstwa to pojęcie ukazujące konkurencyjną pozycję przedsiębiorstwa na rynku, jego wiarygodność i siłę ekonomiczną, która kształtuje poziom zaufania kontrahentów oraz opinie o danym podmiocie gospodarczym $^{36}$. W szerokim ujęciu rozumiany jest jako sytuacja finansowa podmiotu gospodarczego, której wyznacznikami są zasoby majątkowe, nowoczesność procesu technologicznego i produktów, jakość personelu, wyposażenie w kapitał, sprawność zarządzania, osiagane wyniki, dostęp do efektywnych źródeł finansowania, siła rynkowa, charakter branży, lojalność kontrahentów, reputacja, wiarygodność itp. ${ }^{37}$

W literaturze przedmiotu dotychczas nie wydzielono mierników standingu finansowego, które wyraźnie odnosiłyby się do specyfiki klubów sportowych jako podmiotów gospodarczych. Przykładowo, w raporcie „Ekstraklasa piłkarskiego biznesu 2011", stworzonym przez firmę audytową Ernst \& Young, przy sporządzaniu rankingu klubów Ekstraklasy z perspektywy finansowej posłużono się szeregiem kryteriów, którym w następnej kolejności przypisano określone wagi (zob. tab. 4).

Tabela 4

Kryteria uwzględniane przy ocenie klubów Ekstraklasy z perspektywy finansowej w 2011 r.

\begin{tabular}{|c|l|c|}
\hline Lp. & \multicolumn{1}{|c|}{ Kryterium } & Waga \\
\hline \hline 1. & Wysokość przychodów w 2010 r. & $25 \%$ \\
\hline 2. & Wskaźnik dywersyfikacji przychodów w 2010 r. & $15 \%$ \\
\hline 3. & Wskaźnik obciążenia majątku zobowiązaniami na koniec 2010 r. & $15 \%$ \\
\hline 4. & Wskaźnik rentowności netto w 2010 r. & $15 \%$ \\
\hline 5. & Wskaźnik płynności bieżącej na koniec 2010 r. & $10 \%$ \\
\hline 6. & Suma aktywów trwałych według bilansów klubów na koniec 2010 r. & $10 \%$ \\
\hline 7. & Wskaźnik płynności gotówkowej na koniec 2010 r. & $5 \%$ \\
\hline 8. & Dynamika przychodów w latach 2009-2010 & $5 \%$ \\
\hline
\end{tabular}

Źr ódło: opracowanie własne na podstawie raportu „Ekstraklasa piłkarskiego biznesu 2011”.

Należy pamiętać, iż przedstawione kryteria znalazły zastosowanie przy ocenie klubów piłkarskich występujących w tej samej lidze i co za tym idzie w podobnym otoczeniu sportowym, ekonomicznym, marketingowym itp.

wynosił 0,84 zł. Świadczy to o fakcie, iż od momentu debiutu na giełdzie akcje klubu straciły na wartości ponad $42 \%$.

${ }^{36}$ W. B i eń, Zarzqdzanie finansami przedsiębiorstw, Difin, Warszawa 1991, s. 81.

${ }^{37}$ Stownik Ekonomiczny PWN, serwis internetowy PWN Biznes www.biznes.pwn.pl. 
Znaczna część z nich nie będzie uwzględniana przy ocenie standingu finansowego klubów piłkarskich notowanych w indeksie Stoxx Europe Football. Jest to spowodowane faktem, że badane podmioty są przedstawicielami rozmaitych lig piłkarskich, które są zróżnicowane pod wieloma względami. Bardzo ciężko jednoznacznie porównać wysokość przychodów osiaganych np. przez Juventus Turyn i Ajax Amsterdam. Włoskie kluby piłkarskie generalnie charakteryzują się większymi przychodami, aniżeli kluby z Holandii. Jednocześnie ponoszą one wyższe koszty związane z prowadzeniem działalności operacyjnej. Zdaniem autora, dopiero zestawienie obu tych pozycji finansowych może pozwolić na pełniejsze spojrzenie na finansową perspektywę danego podmiotu. Podobna sytuacja zachodzi w przypadku wskaźnika dywersyfikacji przychodów. We wspomnianym raporcie „Ekstraklasa piłkarskiego biznesu 2011” premiowano te kluby, które były w stanie generować zbliżony poziom przychodów z różnych źródeł, wśród których żaden nie dominował istotnie nad pozostałymi ${ }^{38}$. Praktyka biznesowa klubów piłkarskich z różnych lig Europy jest jednak zdecydowanie inna. Przykładowo, FC Porto od lat uchodzi za wzór klubu piłkarskiego, który funkcjonuje w głównej mierze w oparciu o „zakup” piłkarzy za stosunkowo niską kwotę, a następnie ich „odsprzedaż” za sumę wielokrotnie wyższą. Ponadto uzyskiwane przez portugalskie kluby kwoty za sprzedaż praw do transmisji meczów nigdy nie będą tak duże, jak w przypadku klubów z Anglii, Niemiec czy Włoch.

Do badania struktury finansowania przedsiębiorstwa wykorzystywane są miary zadłużenia. Określają poziom jego zadłużenia i tym samym oceniają jego wypłacalność $\mathrm{w}$ długim okresie ${ }^{39}$. W analizie wykorzystano następujące mierniki zadłużenia ${ }^{40}$ :

- wspótczynnik ogólnego zadtużenia, który stanowi relację zobowiązań ogółem do całkowitych aktywów przedsiębiorstwa i wyraża udział kapitałów obcych w finansowaniu aktywów. Wysokie poziomy współczynnika (powyżej 0,5) oznaczają duży udział długu w działalności przedsiębiorstwa i przez to znaczne ryzyko ewentualnego bankructwa w wypadku pogorszenia się koniunktury ${ }^{41}$.

${ }^{38}$ We wspomnianym opracowaniu niską pozycję zajmują kluby których znacząca część przychodów pochodzi w większości od jednego sponsora, bądź których finansowanie opiera się w przeważającej części na wpływach z praw telewizyjnych. Więcej w: Ekstraklasa pitkarskiego biznesu 2011, Ernst \& Young, Warszawa 2011, s. 5.

${ }^{39}$ T. W a śni e w ski, W. S k o c zy las, Analiza finansowa $w$ przedsiębiorstwie, WSB, Poznań, 1997, s. 55.

${ }^{40}$ Szczególna uwaga skupiona została na dynamice oraz tendencji zmian poszczególnych wskaźników w zależności od osiągniętego wyniku sportowego. W badaniach korzystano ze sprawozdań finansowych opublikowanych bądź na oficjalnych stronach internetowych klubów piłkarskich poddanych ocenie, bądź też w serwisie giełdowym www.investing.businessweek.com. Wszelkie kwoty odnoszące się do sfery finansowej klubów zagranicznych wyrażone zostały w walucie EUR. W przypadku Ruchu Chorzów kwoty wyrażono w walucie PLN.

${ }^{41}$ Strona internetowa Skanera Rynku Giełdowego www.sindicator.net. Wielu badaczy uważa, że optymalna wartość tego wskaźnika zależy od branży, w której przedsiębiorstwo działa. Im wyższy jest jego poziom, tym wyższy poziom zadłużenia i wyższe ryzyko finansowe. 
wspótczynnik ogólnego zadtużenia $=($ zobowiazania ogótem / aktywa ogótem $) \times 100$

- wspótczynnik pokrycia zobowiazań nadwyżka finansowa, który odpowiada na pytanie, jaką część zobowiązań ogółem przedsiębiorstwo jest w stanie spłacić przy pomocy wygospodarowanej nadwyżki finansowej. Wzrost miernika oznacza skrócenie czasu potrzebnego jednostce na spłatę zadłużenia. Ponadto uwzględnia on amortyzację, która stanowi istotną pozycję w bilansie klubu piłkarskiego (w szczególności odnosi się to do rocznych stawek amortyzacyjnych w przypadku praw do kart zawodniczych stanowiących składnik wartości niematerialnych i prawnych ${ }^{42}$ ).

wspótczynnik pokrycia zobowiqzań nadwyżka finansowa $=$ $[($ zysk netto + amortyzacja $) /$ zobowiazania ogótem $] \times 100$

Ponadto przy ocenie standingu finansowego klubów piłkarskich wykorzystano:

- wspótczynnik rentowności netto, będący zrelacjonowaną kwotą wyniku netto do przychodów $z$ działalności podstawowej ${ }^{43}$. Im wyższa wartość miernika, tym sprzedaż jest bardziej opłacalna.

wspótczynnik rentowności netto $=$ zysk netto $/$ przychody ze sprzedaży $\times 100$

- wskaźnik dynamiki wartości sprzedaży, przedstawiający relację poziomu wartości sprzedaży w danym roku do jej poziomu w roku ubiegłym. Wskaźnik ten jest podstawowym narzędziem obrazującym (w ujęciu procentowym), ile w ciągu roku zwiększyły się (lub zmniejszyły się) przychody ze sprzedaży netto. Jego formułę można przedstawić następująco:

wskaźnik dynamiki wartości sprzedaży = przychody ze sprzedaży rozpatrywanego okresu $\times 100 /$ przychody ze sprzedaży poprzedniego okresu

Z analizy wyników przeprowadzonych badań zauważyć można, że w horyzoncie czasowym 2008-2011 Ruch Chorzów był zdecydowanie najbardziej zadłużonym klubem piłkarskim (zob. tab. 5). Wartości współczynnika ogólnego zadłużenia dla tego podmiotu wahały się w zależności od roku od około $162 \%$

${ }^{42} \mathrm{~W}$ przypadku klubów piłkarskich najistotniejszą pozycją jest amortyzacja wartości firmy i wartości niematerialnych i prawnych (ang. Amortization of Goodwill and Intangible Assets). Przykładowo, klub piłkarski Legia Warszawa roczną stawkę amortyzacyjną w przypadku praw do kart zawodniczych określa w oparciu o czas, na jaki został zawarty indywidualny kontrakt z zawodnikiem i podlega ona odpowiedniej aktualizacji w przypadku zmiany długości trwania kontraktu. Warto kart zawodniczych jest podwyższana o wartość wynagrodzeń menedżerów związanych z podpisaniem kontraktów zakupu praw do kart zawodniczych (K. Maksymiuk, op. cit.).

${ }^{43}$ M. Marc in ko w s k a, Ocena działalności instytucji finansowych, Difin, Warszawa 2007, s. 271. 
(rok 2010) do ponad $411 \%$ (rok 2011). Świadczy to o niezwykle dużym udziale długu w działalności klubu i jednocześnie źle rokuje finansową przyszłość Ruchu Chorzów (zob. rys. 2). Wysokie współczynniki ogólnego zadłużenia charakterystyczne są także dla klubów piłkarskich z Włoch oraz Portugalii. Z kolei najniższe wartości opisywanego miernika odnotowano w stosunku do francuskiego Olympique Lyon oraz holenderskiego Ajaxu Amsterdam. Współczynnik ogólnego zadłużenia dla tych klubów w badanym okresie ani razu nie przekroczył $60 \%$, co wskazuje na niewielkie ryzyko ewentualnego bankructwa w przyszłości. Warto dodać, iż w badaniu przyjęto następujące kryteria oceny współ-

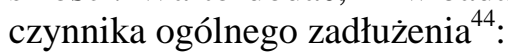

- 0-50\% - bardzo niska wartość współczynnika (bardzo małe ryzyko ewentualnego bankructwa),

- 50,1-75\% - niska wartość współczynnika (niewielkie ryzyko ewentualnego bankructwa),

- 75,1-100\% - wysoka wartość współczynnika (istnieje ryzyko ewentualnego bankructwa w przyszłości),

- 100,1 i więcej - bardzo wysoka wartość współczynnika (znaczne zagrożenie ewentualnym bankructwem).

Tabela 5

Współczynniki ogólnego zadłużenia wybranych klubów piłkarskich notowanych na Stoxx Europe Football Index w latach 2008-2011 (w \%)

\begin{tabular}{|c|c|c|c|c|c|}
\hline \multirow{2}{*}{ Kraj } & \multirow{2}{*}{ Klub } & \multicolumn{4}{|c|}{ Współczynnik ogółem w latach } \\
\hline & & 2008 & 2009 & 2010 & 2011 \\
\hline Niemcy & Borussia Dortmund & 70,50 & 70,23 & 71,14 & 69,51 \\
\hline \multirow{3}{*}{ Włochy } & AS Roma & 93,78 & 94,32 & 110,91 & 142,79 \\
\hline & Juventus Turyn & 65,00 & 63,67 & 69,00 & 101,50 \\
\hline & Lazio Rzym & 105,98 & 98,68 & 99,70 & 93,64 \\
\hline Francja & Olympique Lyon & 52,73 & 43,99 & 53,83 & 59,73 \\
\hline Holandia & Ajax Amsterdam & 47,72 & 50,91 & 59,08 & 55,30 \\
\hline \multirow{3}{*}{ Portugalia } & Benfica Lizbona & 84,47 & 107,07 & 98,06 & 99,35 \\
\hline & FC Porto & 88,85 & 87,58 & 87,53 & 89,66 \\
\hline & Sporting Lizbona & 101,81 & 112,57 & 132,57 & 117,42 \\
\hline Polska & Ruch Chorzów & 189,47 & 262,50 & 162,22 & 411,36 \\
\hline
\end{tabular}

Źródło: opracowanie własne na podstawie badań sprawozdań finansowych giełdowych spółek akcyjnych.

${ }^{44}$ Zgodnie z teorią analizy fundamentalnej, kryteria ewaluacji poszczególnych miar efektywności finansowej są zróżnicowane w zależności od rodzaju przedsiębiorstw i charakteru ich działalności. W literaturze przedmiotu nie wyodrębniono dotąd kryteriów oceny wartości: współczynnika ogólnego zadłużenia, współczynnika pokrycia zobowiązań nadwyżką finansową, współczynnika rentowności netto oraz wskaźnika dynamiki wartości sprzedaży dla przedsiębiorstw sportowych. Przyjęte w artykule kryteria kategoryzacji ocen ww. miar efektywności finansowej klubów piłkarskich zostały zaproponowane przez autora opracowania. 


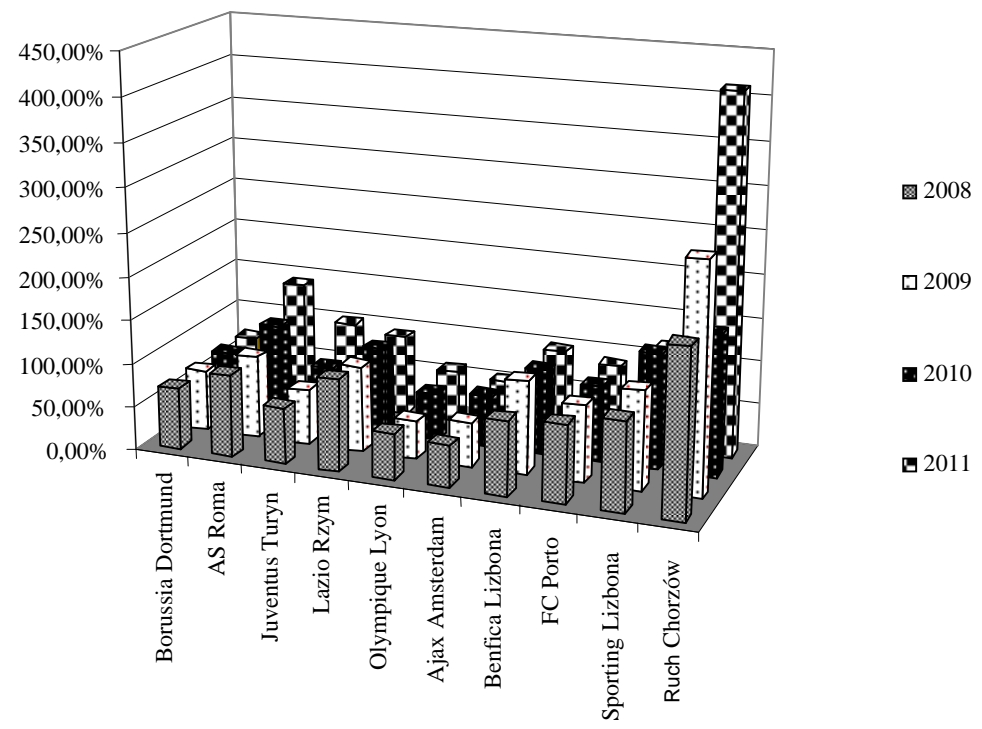

Rys. 2. Współczynniki ogólnego zadłużenia wybranych klubów piłkarskich notowanych na Stoxx Europe Football Index w latach 2008-2011 (w \%)

Źródło: opracowanie własne.

Warto zauważyć, że jedynie w AS Roma miała miejsce niekorzystna tendencja ustawicznego wzrostu wskaźnika dynamiki współczynnika ogólnego zadłużenia obliczonego ,rok do roku” (zob. tab. 6). Jednocześnie należy stwierdzić, że podobnie zła sytuacja dotyczy innego włoskiego klubu - Juventusu Turyn. Dla tego podmiotu w roku 2010 zanotowano niewielki wzrost opisywanego miernika. Jednak już rok później zaobserwowano znaczny wzrost opisywanego miernika (dynamika zmian współczynnika wyniosła wówczas ponad 147\%). Najmniejsze wahania współczynnika ogólnego zadłużenia charakterystyczne były dla Borussii Dortmund (dynamika zmian na poziomie 97,7-101,3\%) oraz FC Porto (dynamika zmian na poziomie 98,6-102,4\%). Trudno jednoznacznie ocenić przypadek chorzowskiego Ruchu. W 2010 r. klub ten osiagnął pozytywny, rekordowy spadek opisywanego miernika (dynamika zmian współczynnika wyniosła $61,8 \%$ ). $\mathrm{Z}$ kolei $\mathrm{w}$ roku następnym uzyskał bardzo znaczny wzrost współczynnika ogólnego zadłużenia $(253,6 \%)$.

Wyraźne rozbieżności zachodzą w przypadku współczynnika pokrycia zobowiązań nadwyżką finansową (zob. tab. 7 i rys. 3). Z analizy uzyskanych w toku badań wyników można zaobserwować, że najkorzystniejsze wartości tegoż miernika odnotowano w przypadku Ajaxu Amsterdam. W 2008 i 2011 r. ten klub był $\mathrm{w}$ stanie spłacić blisko połowę swoich zobowiązań z uzyskanej 
nadwyżki finansowej. Ogólnie wysokie wartości współczynnika charakterystyczne były także dla takich klubów, jak: FC Porto, Lazio Rzym oraz Olympique Lyon. Natomiast najgorsze wyniki odnotowano w przypadku Sportingu Lizbona oraz Ruchu Chorzów. Pierwszy ze wspomnianych klubów niekorzystne wyniki tłumaczyć może wysokimi stratami netto zanotowanymi w latach 20092011 i wynoszącymi od -13,3 mln EUR do -44 mln EUR. Z kolei w przypadku Ruch Chorzów ujemne, bardzo wysokie wartości współczynnika pokrycia zobowiązań nadwyżką finansową (wynoszące w 2008 i 2011 r. ponad -50\%) wynikaja $\mathrm{z}$ uzyskanych strat finansowych na poziomie $-4,7 \mathrm{mln}$ PLN (2008 r.) i -10,9 mln PLN (2011 r.). Należy pamiętać, iż wartości opisywanego wskaźnika są w bardzo dużej mierze uzależnione od wysokich kwot amortyzacji wykazywanych przez badane kluby w swoich sprawozdaniach finansowych. W analizie przyjęto następujące kryteria oceny współczynnika pokrycia zobowiązań nadwyżką finansową:

- wartości ujemne do 0\% - bardzo niska wartość współczynnika (brak jakiejkolwiek możliwości spłaty zobowiązań z nadwyżki finansowej),

- 0,1-15\% - niska wartość współczynnika (niewielka możliwość spłaty zobowiązań z wygenerowanej nadwyżki finansowej),

- 15,1-30\% - wysoka wartość współczynnika (możliwość spłaty znacznej części zobowiązań z nadwyżki finansowej),

- 30,1\% i więcej - bardzo wysoka wartość współczynnika (możliwość uregulowania bardzo dużej części zobowiązań z nadwyżki finansowej).

Tabela 6

Dynamika zmian współczynników ogólnego zadłużenia (wraz z tendencją zmian) wybranych klubów piłkarskich notowanych na Stoxx Europe Football Index w latach 2000-2011 (w \%)

\begin{tabular}{|c|c|c|c|c|c|c|}
\hline \multirow{2}{*}{ Klub } & \multicolumn{6}{|c|}{ Dynamika zmian współczynnika ogółem w latach wraz z tendencją zmian } \\
\hline & $2009 / 2008$ & zmiana & $2010 / 2009$ & zmiana & $2011 / 2010$ & zmiana \\
\hline Borussia Dortmund & 99,62 & $\bar{k}$ & 101,30 & $\pi$ & 97,71 & $\bar{k}$ \\
\hline AS Roma & 100,58 & $\pi$ & 117,59 & $\pi$ & 128,74 & $\pi$ \\
\hline Juventus Turyn & 97,95 & $\bar{K}$ & 108,37 & $\pi$ & 147,10 & $\uparrow$ \\
\hline Lazio Rzym & 93,11 & K & 101,03 & $\pi$ & 93,92 & $\boldsymbol{K}$ \\
\hline Olympique Lyon & 83,42 & $\boldsymbol{k}$ & 122,37 & $\pi$ & 110,96 & $\pi$ \\
\hline Ajax Amsterdam & 106,68 & $\pi$ & 116,05 & $\pi$ & 93,60 & $\boldsymbol{k}$ \\
\hline Benfica Lizbona & 126,76 & $\uparrow$ & 91,58 & $\boldsymbol{K}$ & 101,32 & $\pi$ \\
\hline FC Porto & 98,57 & $\boldsymbol{k}$ & 99,94 & $\boldsymbol{k}$ & 102,43 & $\pi$ \\
\hline Sporting Lizbona & 110,57 & $\pi$ & 117,77 & $\pi$ & 88,57 & $\boldsymbol{K}$ \\
\hline Ruch Chorzów & 138,54 & $\uparrow$ & 61,80 & $\downarrow$ & 253,58 & $\uparrow$ \\
\hline $\begin{array}{l}\boldsymbol{\uparrow} \text { - wyraźny wzrost ( } \\
\boldsymbol{\lambda} \text { - niewielki wzrost } \\
\boldsymbol{L} \text { - niewielki spadek } \\
\downarrow \text { - wyraźny spadek }\end{array}$ & $\begin{array}{l}\text { mika zmia } \\
\text { amika zmia } \\
\text { amika zmic } \\
\text { amika zmia }\end{array}$ & $\begin{array}{l}\text { owyże } \\
\text { v prze } \\
N \text { prze } \\
\text { oniżej }\end{array}$ & $\begin{array}{l}5 \%) \\
\text { e } 100,1- \\
\text { le } 75-99\end{array}$ & & & \\
\hline
\end{tabular}

Źródło: jak do tab. 5. 
Tabela 7

Współczynniki pokrycia zobowiązań nadwyżką finansową wybranych klubów piłkarskich notowanych na Stoxx Europe Football Index w latach 2008-2011 (w \%)

\begin{tabular}{|c|l|r|r|r|r|}
\hline \multirow{2}{*}{ Kraj Klub } & \multicolumn{3}{|c|}{ Współczynnik ogółem w latach } \\
\cline { 3 - 6 } & Borussia Dortmund & \multicolumn{1}{|c|}{2008} & \multicolumn{1}{|c|}{2009} & \multicolumn{1}{c|}{2010} & \multicolumn{1}{c|}{2011} \\
\hline \hline \multirow{3}{*}{ Niemcy } & AS Roma & $27,94 \%$ & $7,08 \%$ & $7,18 \%$ & $14,80 \%$ \\
\hline \multirow{3}{*}{ Włochy } & Juventus Turyn & $6,05 \%$ & $21,8,82 \%$ & $1,56 \%$ & $-6,08 \%$ \\
\cline { 2 - 6 } & Lazio Rzym & $14,53 \%$ & $15,37 \%$ & $12,19 \%$ & $-17,32 \%$ \\
\hline Francja & Olympique Lyon & $26,01 \%$ & $\mathbf{3 0 , 5 8 \%}$ & $4,27 \%$ & $18,94 \%$ \\
\hline Holandia & Ajax Amsterdam & $\mathbf{4 6 , 4 0 \%}$ & $22,31 \%$ & $-5,65 \%$ & $9,85 \%$ \\
\hline \multirow{3}{*}{ Portugalia } & Benfica Lizbona & $13,27 \%$ & $-7,56 \%$ & $2,51 \%$ & $\mathbf{4 6 , 6 5 \%}$ \\
\cline { 2 - 6 } & FC Porto & $20,55 \%$ & $17,48 \%$ & $\mathbf{1 6 , 0 5 \%}$ & $13,22 \%$ \\
\cline { 2 - 6 } & Sporting Lizbona & $5,27 \%$ & $-1,19 \%$ & $-7,40 \%$ & $-13,63 \%$ \\
\hline Polska & Ruch Chorzów & $\mathbf{- 5 4 , 1 7 \%}$ & $\mathbf{- 9 , 5 2 \%}$ & $\mathbf{3 2 , 8 8 \%}$ & $\mathbf{- 5 6 , 9 1 \%}$ \\
\hline
\end{tabular}

Źródło: jak do tab. 5.

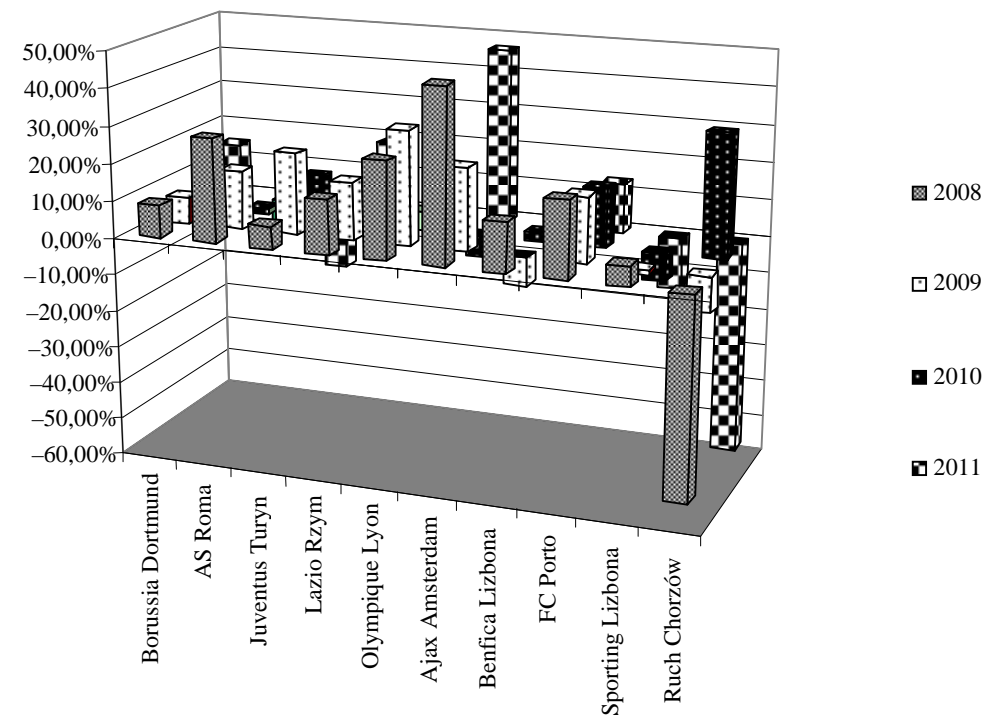

Rys. 3. Współczynniki pokrycia zobowiązań nadwyżką finansową wybranych klubów piłkarskich notowanych na Stoxx Europe Football Index w latach 2008-2011 (w \%)

Źródło: opracowanie własne. 
Najwyższą rentowność netto sprzedaży na przestrzeni lat 2008-2011 wykazał się klub FC Porto, który corocznie generował zysk na podstawowej, prowadzonej przez siebie działalności, wahający się od $0,17 \%$ do $14,98 \%$ (tab. 8 , rys. 4). Lazio Rzym jedynie w 2010 r. odnotował ujemną stopę marży zysku netto, lecz stanowiła ona zaledwie $-2,07 \%$. W pozostałych latach klub osiagał wysoką rentowność netto sprzedaży, wynosząca od $13,53 \%$ do $15,01 \%$. Stosunkową stabilność w tym względzie wykazała niemiecka Borussia Dortmund. Natomiast najbardziej niekorzystne wartości opisywanego miernika charakterystyczne były dla Sportingu Lizbona, który jedynie w 2008 r. uzyskał niewielką dodatnią stope marży operacyjnej, a w kolejnych latach odnotował wysokie ujemne wartości współczynnika wahające się w przedziale $-36,84 \%$ do $-136,65 \%$ oraz Ruchu Chorzów, który zysk z działalności podstawowej wygenerował jedynie w 2010 r., a w pozostałych latach uzyskiwał wysokie starty i ujemne wartości współczynnika rentowności netto wynoszące nawet $-110 \%$. W badaniu przyjęto następujące kryteria oceny współczynnika rentowności netto:

- wartości ujemne do 0\% - bardzo niska wartość współczynnika (brak rentowności netto - deficytowość),

- 0,1-5\% - niska wartość współczynnika (niewielka rentowność netto sprzedaży),

- 5,1-10\% - wysoka wartość współczynnika (znaczna rentowność netto sprzedaży),

- 10,1\% i więcej - bardzo wysoka wartość współczynnika (wysoka rentowność netto sprzedaży klubu piłkarskiego).

Tabela 8

Współczynniki rentowności netto wybranych klubów piłkarskich notowanych na Stoxx Europe Football Index w latach 2008-2011 (w \%)

\begin{tabular}{|c|l|r|r|r|r|}
\hline \multirow{2}{*}{ Kraj Klub } & \multicolumn{3}{|c|}{ Współczynnik ogółem w latach } \\
\cline { 3 - 6 } & Borussia Dortmund & \multicolumn{1}{|c|}{2008} & \multicolumn{1}{|c|}{2009} & \multicolumn{1}{c|}{2010} & \multicolumn{1}{c|}{2011} \\
\hline \hline \multirow{3}{*}{ Niemcy } & AS Roma & $10,68 \%$ & $-5,23 \%$ & $-5,63 \%$ & $3,50 \%$ \\
\hline \multirow{3}{*}{ Włochy } & Juventus Turyn & $-10,21 \%$ & $2,73 \%$ & $-16,68 \%$ & $-21,77 \%$ \\
\cline { 2 - 6 } & Lazio Rzym & $14,42 \%$ & $\mathbf{1 5 , 0 1 \%}$ & $-2,01 \%$ & $-54,99 \%$ \\
\hline Francja & Olympique Lyon & $12,78 \%$ & $3,65 \%$ & $-24,23 \%$ & $-21,08 \%$ \\
\hline Holandia & Ajax Amsterdam & $12,60 \%$ & $-5,06 \%$ & $-33,00 \%$ & $5,66 \%$ \\
\hline \multirow{3}{*}{ Portugalia } & Benfica Lizbona & $0,24 \%$ & $\mathbf{- 8 4 , 7 1 \%}$ & $-31,83 \%$ & $-11,85 \%$ \\
\cline { 2 - 6 } & FC Porto & $\mathbf{1 4 , 9 8 \%}$ & $7,91 \%$ & $0,17 \%$ & $0,67 \%$ \\
\cline { 2 - 6 } & Sporting Lizbona & $1,60 \%$ & $-36,84 \%$ & $\mathbf{- 8 9 , 8 3 \%}$ & $\mathbf{- 1 3 6 , 6 5 \%}$ \\
\hline Polska & Ruch Chorzów & $\mathbf{- 4 8 , 9 6 \%}$ & $-13,82 \%$ & $\mathbf{9 , 6 0 \%}$ & $-110,10 \%$ \\
\hline
\end{tabular}

Źródło: jak do tab. 5. 
$\mathrm{Z}$ analizy przeprowadzonych badań wynika, że jedynie Ajax Amsterdam corocznie generował coraz to większe przychody netto ze sprzedaży (zob. tab. 9). W 2011 r. wskaźnik dynamiki przychodów ze sprzedaży dla tego klubu wyniósł aż $140 \%$. Bardzo dobre wyniki w tym zakresie uzyskała też Benfica Lizbona. Portugalski klub najniższą wartość wskaźnika zanotował w 2009 r., lecz wyniosła on aż 99,76\%. W roku kolejnym Benfica uzyskała rekordową wartość opisywanego miernika, wynoszącą blisko $145 \%$. Największe wahania wskaźnika dynamiki przychodów ze sprzedaży charakterystyczne były dla chorzowskiego Ruchu. Z kolei najmniejsze zmiany jego wartości zauważono w przypadku takich klubów, jak: Olympique Lyon czy rzymskich: AS Roma i Lazio. Warto zwrócić uwagę na niekorzystną sytuację dotyczącą słynnego Juventusu Turyn. Klub ten z roku na rok notuje coraz większe spadki dynamiki przychodów ze sprzedaży, co może źle rokować na jego finansową przyszłość.

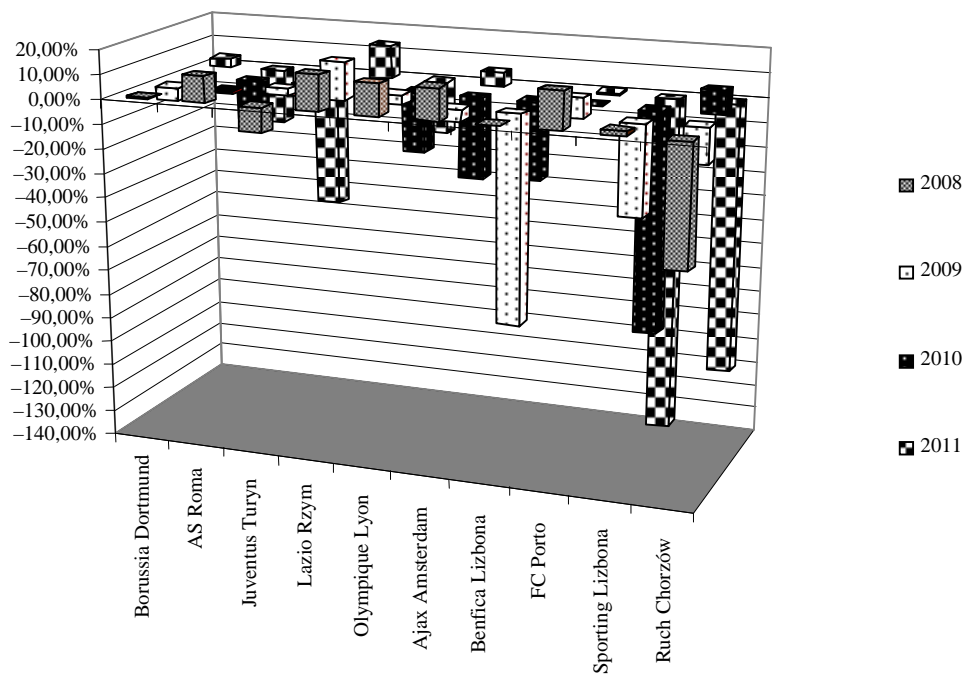

Rys. 4. Współczynniki rentowności netto wybranych klubów piłkarskich notowanych na Stoxx

Europe Football Index w latach 2008-2011 (w \%)

Źródło: opracowanie własne. 
Wskaźniki dynamiki przychodów ze sprzedaży (wraz z tendencją zmian) wybranych klubów piłkarskich notowanych na Stoxx Europe Football Index w latach 2008-2011 (w \%)

\begin{tabular}{|c|c|c|c|c|c|c|}
\hline \multirow{2}{*}{ Klub } & \multicolumn{6}{|c|}{ Wskaźnik ogółem w latach wraz z tendencją zmian } \\
\hline & $2009 / 2008$ & zmiana & $2010 / 2009$ & zmiana & $2011 / 2010$ & zmiana \\
\hline Borussia Dortmund & $101,41 \%$ & $\pi$ & $95,99 \%$ & $\boldsymbol{K}$ & $137,60 \%$ & 个 \\
\hline AS Roma & $86,64 \%$ & $\boldsymbol{K}$ & $84,71 \%$ & $\boldsymbol{K}$ & $107,28 \%$ & $\pi$ \\
\hline Juventus Turyn & $118,75 \%$ & $\pi$ & $90,82 \%$ & $\boldsymbol{k}$ & $78,97 \%$ & $\downarrow$ \\
\hline Lazio Rzym & $84,22 \%$ & $\boldsymbol{k}$ & $102,11 \%$ & $\pi$ & $89,79 \%$ & $\boldsymbol{k}$ \\
\hline Olympique Lyon & $89,66 \%$ & $\boldsymbol{k}$ & $104,66 \%$ & $\pi$ & $90,90 \%$ & $\boldsymbol{k}$ \\
\hline Ajax Amsterdam & $108,56 \%$ & $\pi$ & $102,83 \%$ & $\pi$ & $140,52 \%$ & $\uparrow$ \\
\hline Benfica Lizbona & $99,76 \%$ & $\boldsymbol{k}$ & $144,90 \%$ & $\uparrow$ & $108,88 \%$ & $\pi$ \\
\hline FC Porto & $120,79 \%$ & $\uparrow$ & $88,99 \%$ & $\boldsymbol{k}$ & $129,27 \%$ & $\uparrow$ \\
\hline Sporting Lizbona & $96,27 \%$ & $\pi$ & $81,72 \%$ & $\boldsymbol{K}$ & $109,15 \%$ & $\pi$ \\
\hline Ruch Chorzów & $128,13 \%$ & 个 & $143,90 \%$ & $\uparrow$ & $55,93 \%$ & $\downarrow$ \\
\hline \multicolumn{7}{|c|}{$\begin{array}{l}\boldsymbol{\uparrow} \text { - wyraźny wzrost (dynamika zmian powyżej 120\%) } \\
\boldsymbol{\lambda} \text { - niewielki wzrost (dynamika zmian w przedziale } 100,1-120 \% \text { ) } \\
\boldsymbol{K} \text { - niewielki spadek dynamika zmian w przedziale } 80-99,9 \% \text { ) } \\
\downarrow \text { - wyraźny spadek (dynamika zmian poniżej } 80 \% \text { ) }\end{array}$} \\
\hline
\end{tabular}

Źródło: jak do tab. 5.

\section{OCENA WYNIKÓW SPORTOWYCH OSIĄGNIĘTYCH PRZEZ WYBRANE KLUBY PIŁKARSKIE NOTOWANE NA STOXX EUROPE FOOTBALL INDEX W LATACH 2007-2011}

Ocena rezultatów sportowych uzyskanych przez objęte badaniem kluby piłkarskie została sporządzona przy pomocy skorygowanej metody delfickiej ${ }^{45}$. Zastosowanie tej metody miało na celu uzyskanie jak najbardziej obiektywnego spojrzenia przy wartościowaniu uzyskanych wyników. Osiagnięcia sportowe klubów w poszczególnych sezonach zostały podsumowane przez pryzmat wyników zdobytych zarówno w rozgrywkach krajowych, jak i europejskich pucharach. Przy oszacowaniu uzyskanych rezultatów uwzględniano:

- miejsce w tabeli ligowej na koniec sezonu,

- ewentualny triumf w krajowym Pucharze,

${ }^{45}$ Metoda delficka należy do grupy metod heurystycznych, w których do podejmowania decyzji wykorzystuje się wiedzę, doświadczenie i opinie ekspertów z danej dziedziny. Wykorzystywana jest do określenia prawdopodobieństwa zajścia przyszłych wydarzeń. Zastosowana w niniejszych badaniach metoda różni się od tradycyjnej metody delfickiej faktem, iż postawiona prognoza nie została uzyskana za pomocą ankiet przeprowadzanych wśród ekspertów. Zamiast tego opinie zostały zaczerpnięte z serii materiałów prasowych (tzw. Skarbów Kibica, programów przedsezonowych itp.), w których eksperci prezentowali swoje stanowisko odnośnie oczekiwań sportowych wobec poszczególnych klubów piłkarskich biorących udział w badaniu. 
- ewentualny triumf w krajowym Superpucharze,

- osiągnięcia w Lidze Mistrzów,

- oraz osiagnięcia w Pucharze UEFA i Lidze Europy.

$\mathrm{Na}$ tej podstawie sporządzono zestawienie najważniejszych rezultatów sportowych uzyskanych przez kluby piłkarskie biorące udział w badaniu (zob. tab. 10). Następnie faktycznie uzyskane wyniki sportowe zostały skonfrontowane z przedsezonowymi oczekiwaniami, wyrażanymi przez osoby profesjonalnie zajmujące się piłkarskim rynkiem w Europie. Umożliwiło to dokonanie ogólnej kompleksowej oceny osiągnięć piłkarskich uzyskanych przez poszczególne podmioty uwzględnione $\mathrm{w}$ analizie. $\mathrm{W}$ konsekwencji wydzielono następujące oceny możliwe do zdobycia:

$-\leftarrow \rightarrow$ - rezultaty zgodne z przedsezonowymi oczekiwaniami,

- - rezultaty powyżej oczekiwań,

- $\downarrow$ - rezultaty poniżej oczekiwań.

Tabela 10

Najważniejsze wyniki sportowe osiagnięte przez kluby biorące udział w badaniu w sezonach 2007/2008-2010/2011

\begin{tabular}{|c|c|c|c|c|}
\hline \multirow{2}{*}{ AJAX AMSTERDAM } & \multicolumn{4}{|c|}{ Sezon } \\
\cline { 2 - 5 } & $2007 / 2008$ & $2008 / 2009$ & $2009 / 2010$ & $2010 / 2011$ \\
\hline \hline Rozgrywki krajowe & $\begin{array}{c}2 \text { miejsce } \\
\text { w lidze }\end{array}$ & $\begin{array}{c}3 \text { miejsce } \\
\text { w lidze }\end{array}$ & $\begin{array}{c}2 \text { miejsce } \\
\text { w lidze, Puchar } \\
\text { Holandii }\end{array}$ & $\begin{array}{c}\text { Mistrzostwo } \\
\text { ligi }\end{array}$ \\
\hline Europejskie puchary & $\begin{array}{c}\text { Eliminacje } \\
\text { p. UEFA }\end{array}$ & $1 / 8$ p. UEFA & $\begin{array}{c}1 / 16 \text { Ligi } \\
\text { Europy }\end{array}$ & $\begin{array}{c}1 / 8 \text { Ligi } \\
\text { Europy }\end{array}$ \\
\hline Ogólna ocena & $\downarrow$ & $\leftarrow \rightarrow$ & $\leftarrow \rightarrow$ & $\uparrow$ \\
\hline
\end{tabular}

\begin{tabular}{|c|c|c|c|c|}
\hline \multirow{2}{*}{ AS ROMA } & \multicolumn{4}{|c|}{ Sezon } \\
\cline { 2 - 5 } & $2007 / 2008$ & $2008 / 2009$ & $2009 / 2010$ & $2010 / 2011$ \\
\hline \hline Rozgrywki krajowe & $\begin{array}{c}2 \text { miejsce } \\
\text { w lidze, Pu- } \\
\text { char Włoch }\end{array}$ & $\begin{array}{c}6 \text { miejsce } \\
\text { w lidze }\end{array}$ & $\begin{array}{c}2 \text { miejsce } \\
\text { w lidze }\end{array}$ & $\begin{array}{c}\text { 6 miejsce } \\
\text { w lidze }\end{array}$ \\
\hline Europejskie puchary & $\begin{array}{c}1 / 4 \text { Ligi Mi- } \\
\text { strzów }\end{array}$ & $\begin{array}{c}1 / 16 \text { Ligi } \\
\text { Mistrzów }\end{array}$ & $\begin{array}{c}1 / 16 \text { Ligi } \\
\text { Europy }\end{array}$ & $\begin{array}{c}1 / 16 \text { Ligi } \\
\text { Mistrzów }\end{array}$ \\
\hline Ogólna ocena & $\uparrow$ & $\downarrow$ & $\leftarrow \rightarrow$ & $\downarrow$ \\
\hline
\end{tabular}

\begin{tabular}{|c|c|c|c|c|}
\hline \multirow{2}{*}{ LAZIO RZYM } & \multicolumn{4}{|c|}{ Sezon } \\
\cline { 2 - 5 } & $2007 / 2008$ & $2008 / 2009$ & $2009 / 2010$ & $2010 / 2011$ \\
\hline \hline Rozgrywki krajowe & $\begin{array}{c}12 \text { miejsce } \\
\text { w lidze }\end{array}$ & $\begin{array}{c}10 \text { miejsce } \\
\text { w lidze, Pu- } \\
\text { char Włoch }\end{array}$ & $\begin{array}{c}12 \text { miejsce } \\
\text { w lidze, Super- } \\
\text { puchar Włoch }\end{array}$ & $\begin{array}{c}5 \text { miejsce } \\
\text { w lidze }\end{array}$ \\
\hline Europejskie puchary & - & - & $\begin{array}{c}\text { Faza grupowa } \\
\text { Ligi Europy }\end{array}$ & - \\
\hline Ogólna ocena & $\downarrow$ & $\uparrow$ & $\leftarrow \rightarrow$ & $\uparrow$ \\
\hline
\end{tabular}




\begin{tabular}{|c|c|c|c|c|}
\hline \multirow{2}{*}{ JUVENTUS TURYN } & \multicolumn{4}{|c|}{ Sezon } \\
\cline { 2 - 5 } & $2007 / 2008$ & $2008 / 2009$ & $2009 / 2010$ & $2010 / 2011$ \\
\hline \hline Rozgrywki krajowe & 3 miejsce & 2 miejsce & 7 miejsce & 7 miejsce \\
w lidze & w lidze & widze & lidze \\
\hline Europejskie puchary & - & $\begin{array}{c}1 / 8 \text { Ligi } \\
\text { Mistrzów }\end{array}$ & $\begin{array}{c}1 / 8 \text { Ligi } \\
\text { Europy }\end{array}$ & $\begin{array}{c}\text { Faza grupowa } \\
\text { Ligi Europy }\end{array}$ \\
\hline Ogólna ocena & $\uparrow$ & $\uparrow$ & $\downarrow$ & $\downarrow$ \\
\hline
\end{tabular}

\begin{tabular}{|c|c|c|c|c|}
\hline \multirow{2}{*}{ BORUSSIA DORTMUND } & \multicolumn{4}{|c|}{ Sezon } \\
\cline { 2 - 5 } & $2007 / 2008$ & $2008 / 2009$ & $2009 / 2010$ & $2010 / 2011$ \\
\hline \hline Rozgrywki krajowe & $\begin{array}{c}13 \text { miejsce } \\
\text { w lidze, } \\
\text { Superpuchar } \\
\text { Niemiec }\end{array}$ & $\begin{array}{c}6 \text { miejsce } \\
\text { w lidze }\end{array}$ & $\begin{array}{c}5 \text { miejsce } \\
\text { w lidze }\end{array}$ & $\begin{array}{c}\text { Mistrzostwo } \\
\text { ligi }\end{array}$ \\
\hline Europejskie puchary & - & $\begin{array}{c}\text { Eliminacje } \\
\text { p. UEFA }\end{array}$ & - & $\begin{array}{c}\text { Faza grupowa } \\
\text { Ligi Europy }\end{array}$ \\
\hline Ogólna ocena & $\downarrow$ & $\downarrow$ & $\leftarrow \rightarrow$ & $\uparrow$ \\
\hline
\end{tabular}

\begin{tabular}{|c|c|c|c|c|}
\hline \multirow{2}{*}{ RUCH CHORZÓW } & \multicolumn{4}{|c|}{ Sezon } \\
\cline { 2 - 5 } & $2007 / 2008$ & $2008 / 2009$ & $2009 / 2010$ & $2010 / 2011$ \\
\hline \hline Rozgrywki krajowe & $\begin{array}{c}10 \text { miejsce } \\
\text { w lidze }\end{array}$ & $\begin{array}{c}9 \text { miejsce } \\
\text { w lidze }\end{array}$ & $\begin{array}{c}3 \text { miejsce } \\
\text { w lidze }\end{array}$ & $\begin{array}{c}12 \text { miejsce } \\
\text { w lidze }\end{array}$ \\
\hline Europejskie puchary & - & - & - & $\begin{array}{c}\text { Eliminacje } \\
\text { Ligi Eurpoy }\end{array}$ \\
\hline Ogólna ocena & $\leftarrow \rightarrow$ & $\leftarrow \rightarrow$ & $\uparrow$ & $\downarrow$ \\
\hline
\end{tabular}

\begin{tabular}{|c|c|c|c|c|}
\hline \multirow{2}{*}{ SPORTING LIZBONA } & \multicolumn{4}{|c|}{ Sezon } \\
\hline & $2007 / 2008$ & $2008 / 2009$ & $2009 / 2010$ & $2010 / 2011$ \\
\hline Rozgrywki krajowe & $\begin{array}{c}2 \text { miejsce } \\
\text { w lidze, } \\
\text { Puchar i } \\
\text { Superpuchar } \\
\text { Portugalii, }\end{array}$ & $\begin{array}{c}2 \text { miejsce } \\
\text { w lidze, } \\
\text { Superpuchar } \\
\text { Portugalii }\end{array}$ & $\begin{array}{c}4 \text { miejsce } \\
\text { w lidze }\end{array}$ & $\begin{array}{c}4 \text { miejsce } \\
\text { w lidze }\end{array}$ \\
\hline Europejskie puchary & 1/4 p. UEFA & $\begin{array}{c}\text { 1/8 Ligi } \\
\text { Mistrzów }\end{array}$ & 1/8 Ligi Europy & $\begin{array}{c}1 / 16 \text { Ligi } \\
\text { Europy }\end{array}$ \\
\hline Ogólna ocena & $\uparrow$ & $\leftarrow$ & $\downarrow$ & $\downarrow$ \\
\hline
\end{tabular}

\begin{tabular}{|c|c|c|c|c|}
\hline \multirow{2}{*}{ BENFICA LIZBONA } & \multicolumn{4}{|c|}{ Sezon } \\
\cline { 2 - 5 } & $2007 / 2008$ & $2008 / 2009$ & $2009 / 2010$ & $2010 / 2011$ \\
\hline \hline Rozgrywki krajowe & 4 miejsce & 3 miejsce & Mistrzostwo & 2 miejsce \\
& w lidze & lidgi & lidze \\
\hline Europejskie puchary & $1 / 8$ p. UEFA & $\begin{array}{c}\text { Faza grupowa } \\
\text { p. UEFA }\end{array}$ & $1 / 4$ Ligi Europy & $\begin{array}{c}1 / 2 \text { Ligi } \\
\text { Europy }\end{array}$ \\
\hline Ogólna ocena & $\downarrow$ & $\downarrow$ & $\uparrow$ & $\uparrow$ \\
\hline
\end{tabular}




\begin{tabular}{|c|c|c|c|c|}
\hline \multirow{2}{*}{ FC PORTO } & \multicolumn{4}{|c|}{ Sezon } \\
\hline & $2007 / 2008$ & $2008 / 2009$ & $2009 / 2010$ & $2010 / 2011$ \\
\hline Rozgrywki krajowe & $\begin{array}{l}\text { Mistrzostwo } \\
\text { ligi }\end{array}$ & $\begin{array}{l}\text { Mistrzostwo } \\
\text { ligi }\end{array}$ & $\begin{array}{c}3 \text { miejsce } \\
\text { w lidze, Puchar } \\
\text { Portugalii, } \\
\text { Superpuchar } \\
\text { Portugalii }\end{array}$ & $\begin{array}{l}\text { Mistrzostwo } \\
\text { ligi, } \\
\text { Superpuchar } \\
\text { Portugalii }\end{array}$ \\
\hline Europejskie puchary & $\begin{array}{l}\text { 1/8 Ligi } \\
\text { Mistrzów }\end{array}$ & $\begin{array}{l}\text { 1/4 Ligi } \\
\text { Mistrzów }\end{array}$ & $\begin{array}{l}\text { 1/8 Ligi } \\
\text { Mistrzów }\end{array}$ & $\begin{array}{c}\text { Triumfator } \\
\text { Ligi Europy }\end{array}$ \\
\hline Ogólna ocena & $\uparrow$ & $\uparrow$ & $\leftarrow$ & $\uparrow$ \\
\hline
\end{tabular}

\begin{tabular}{|c|c|c|c|c|}
\hline \multirow{2}{*}{ OLYMPIQUE LYON } & \multicolumn{4}{|c|}{ Sezon } \\
\cline { 2 - 5 } & $2007 / 2008$ & $2008 / 2009$ & $2009 / 2010$ & $2010 / 2011$ \\
\hline \hline Rozgrywki krajowe & $\begin{array}{c}\text { Mistrzostwo ligi, } \\
\text { Puchar Francji }\end{array}$ & $\begin{array}{c}3 \text { miejsce } \\
\text { w lidze }\end{array}$ & $\begin{array}{c}2 \text { miejsce } \\
\text { w lidze }\end{array}$ & $\begin{array}{c}3 \text { miejsce } \\
\text { w lidze }\end{array}$ \\
\hline Europejskie puchary & $\begin{array}{c}1 / 8 \text { Ligi } \\
\text { Mistrzów }\end{array}$ & $\begin{array}{c}1 / 8 \text { Ligi } \\
\text { Mistrzów }\end{array}$ & $\begin{array}{c}1 / 2 \text { Ligi } \\
\text { Mistrzów }\end{array}$ & $\begin{array}{c}1 / 8 \text { Ligi } \\
\text { Mistrzów }\end{array}$ \\
\hline Ogólna ocena & $\uparrow$ & $\leftarrow \rightarrow$ & $\uparrow$ & $\leftarrow \rightarrow$ \\
\hline gdzie: $-\leftarrow \rightarrow-$ rezultaty zgodne z przedsezonowymi oczekiwaniami, \\
$-\uparrow-$ rezultaty powyżej oczekiwań, \\
$-\downarrow-$ rezultaty poniżej oczekiwań.
\end{tabular}

Źródło: opracowanie własne.

Spośród klubów piłkarskich biorących udział w badaniu największe sukcesy sportowe w sezonach 2007/2008-2010/2011 odniósł zespół FC Porto. Drużyna w północy Portugalii w rozpatrywanym okresie trzykrotnie zdobyła mistrzostwo kraju, dwukrotnie krajowy Superpuchar, zaś jeden raz krajowy Puchar. Dodatkowo, w 2011 r. zwyciężyła w Lidze Europy. Warto podkreślić, że w opisywanym okresie był to jedyny triumf w europejskich pucharach spośród drużyn poddanych próbie badawczej. Największy rywal zespołu FC Porto - stołeczna Benfica Lizbona - jedyne mistrzostwo kraju zdobyła w sezonie 2009/2010. $\mathrm{W}$ roku następnym drużyna ta dotarła do półfinału Ligi Europy. Z kolei inny zespół zaliczany do „wielkiej trójki” portugalskiej Ligi Sagres - mianowicie Sporting Lizbona - jedynie sezon 2007/2008 mógł zaliczyć do udanych. W tym czasie drużyna ta zdobyła wicemistrzostwo kraju, wygrała Puchar Portugalii i dotarła do ćwierćfinału Pucharu UEFA.

Jeśli chodzi o kluby z Półwyspu Apenińskiego biorące udział w badaniu, to w sezonach 2007/2008-2010/2011 przedstawiciele włoskiej Serie A osiagali zmienne rezultaty sportowe. AS Roma największe triumfy odnotowała w sezonie 2007/2008, kiedy to wygrała rozgrywki Pucharu Włoch. Rok później jej sukces powtórzyła drużyna rzymskiego Lazio. Warto zwrócić uwagę na zupełnie nieudane występy Juventusu Turyn w latach 2009-2011. Drużyna, której coroczną ambicją jest walka o mistrzostwo Włoch, zajmowała w tym okresie dwukrotnie 7 miejsce w krajowej lidze. 
Biorąc pod uwagę wyniki sportowe osiagane przez pozostałe kluby, warto podkreślić sukcesy Olympique Lyon. Francuska drużyna, obok zdobycia mistrzostwa ligi i zwycięstwa w Pucharze kraju (w sezonie 2007/2008), dwa lata później dotarła do półfinału elitarnej Ligi Mistrzów. Niemiecka Borussia Dortmund jedyne udane występy zanotowała w zasadzie w sezonie 2010/2011, kiedy to zdobyła mistrzostwo kraju. W tym samym okresie jedyny triumf w krajowych rozgrywkach ligowych odnotował holenderski Ajax Amsterdam (rok wcześniej drużyna ta wygrała Puchar Holandii). Pozostałe lata nie przyniosły licznych sportowych sukcesów tym uznanym na europejskiej arenie piłkarskiej klubom. Wyniki sportowe Ruchu Chorzów wskazują, że przedstawiciel polskiej Ekstraklasy zaskakująco dobrze radził sobie w rozgrywkach ligowych w sezonie 2009/2010. Wówczas zają trzecie miejsce i uzyskał prawo reprezentowania naszego kraju w europejskich pucharach. W pozostałych latach drużyna z Górnego Śląska osiagała na koniec sezonu miejsca w dolnej połowie ligowej tabeli.

\section{KSZTAETOWANIE MIAR STANDINGU FINANSOWEGO KLUBÓW SPORTOWYCH W ZALEŻNOŚCI OD OSIĄGANEGO WYNIKU SPORTOWEGO}

Zasadnicze badania oparto na analizie korelacji zachodzących pomiędzy miarami standingu finansowego klubów piłkarskich, a uzyskiwanymi przez nie rezultatami sportowymi. W celu obliczenia tych współzależności wykorzystano współczynniki korelacji rang Spearmana. Warto zaznaczyć, że z myślą o uzyskaniu precyzyjnych danych zdecydowano się na zaprezentowanie w pracy jedynie korelacji o wysokim poziomie istotności równym $\alpha=0,05^{46}$. Przyjęto następującą interpretację wyliczonych współczynników korelacji (r):

- $\mathrm{r}=0$ - współzależność nie występuje,

- $0<|\mathrm{r}|<0,3$ - słaby stopień współzależności,

- $0,3 \leq|\mathrm{r}|<0,5$ - umiarkowany stopień współzależności,

- $0,5 \leq|\mathrm{r}|<0,7$ - znaczny stopień współzależności,

- $0,7 \leq|\mathrm{r}|<0,9$ - wysoki stopień współzależności,

- $|\mathrm{r}| \geq 0,9$ - bardzo wysoki stopień współzależności,

- $|\mathrm{r}|=1$ - współzależność całkowita ${ }^{47}$.

Przeprowadzone badania wykazały, że nie zaobserwowano wyraźnych korelacji zachodzących pomiędzy wartością współczynnika ogólnego zadłużenia wyliczanego dla klubów piłkarskich poddanych analizie, a wynikami sportowymi przez te podmioty osiąganymi (zob. tab. 11). Niska, ujemna wartość współczynnika korelacji (wynosząca $r=-0,205$ ) świadczy, że dobre rezultaty sporto-

${ }^{46}$ Poziom istotności jest to ryzyko popełnienia błędów. W przypadku poziomu istotności $\alpha=0,05$ ryzyko popełnienia błędu zachodzi w 5\% (I. J a żd że w s ka, Statystyka dla geografów, Wydawnictwo Uniwersytetu Łódzkiego, Łódź 2003, s. 169).

${ }^{47}$ Ibidem, s. 161. 
we jedynie w niewielkim stopniu przyczyniają się do zmniejszenia udziału długu w działalności przedsiębiorstwa sportowego.

$\mathrm{Z}$ drugiej strony zauważono występowanie umiarkowanych współzależności zachodzących pomiędzy dynamiką zmian wartości współczynnika ogólnego zadłużenia, a osiaganymi rezultatami sportowymi. Współczynnik korelacji istniejących między opisywanymi parametrami wyniósł $\mathrm{w}$ badaniu $\mathrm{r}=-0,467$ (tab. 11). Oznacza to, że uzyskiwane przez kluby piłkarskie sukcesy sportowe często łączą się z obniżeniem dynamiki współczynnika ogólnego zadłużenia. Jednocześnie świadczy to o istnieniu pozytywnej tendencji polegającej na zmniejszaniu udziału długu w strukturze finansowania tych podmiotów.

$\mathrm{W}$ badaniach zaobserwowano umiarkowany stopień współzależności zachodzących pomiędzy współczynnikiem pokrycia zobowiązań nadwyżką finansową, a uzyskiwanymi rezultatami sportowymi (zob. tab. 11). Wartość współczynnika korelacji wynosząca $r=0,460$ świadczy, że sukces sportowy często może przyczyniać się do zwiększenia części zobowiązań, które przedsiębiorstwo sportowe jest w stanie spłacić przy pomocy wygospodarowanej nadwyżki finansowej. $Z$ drugiej strony gorsze od oczekiwanych wyniki sportowe mogą wydłużyć czas potrzebny jednostce na spłatę zadłużenia.

Tabela 11

Korelacje między miarami standingu finansowego wybranych klubów piłkarskich notowanych na Stoxx Europe Football Index w latach 2007-2011, a uzyskiwanymi przez te kluby rezultatami sportowymi

\begin{tabular}{|c|c|c|c|}
\hline $\begin{array}{c}\text { Parametery, dla których wyliczo- } \\
\text { no współzależności }\end{array}$ & $\begin{array}{c}\text { Wartość } \\
\text { współczynni- } \\
\text { ka korelacji (r) }\end{array}$ & Stopień zależności & Wnioski \\
\hline $\begin{array}{c}\text { Współczynnik ogólnego zadłuże- } \\
\text { nia vs wynik sportowy }\end{array}$ & $\mathrm{r}=-0,205$ & Słaby, ujemny & $\begin{array}{c}\text { Lepsze wyniki sportowe - } \\
\text { mniejsze zadłużenie }\end{array}$ \\
\hline $\begin{array}{c}\text { Dynamika zmian współczynnika } \\
\text { ogólnego zadłużenia vs wynik } \\
\text { sportowy }\end{array}$ & $\mathrm{r}=-0,467$ & $\begin{array}{c}\text { Umiarkowany, } \\
\text { ujemny }\end{array}$ & $\begin{array}{c}\text { Lepsze wyniki sportowe - } \\
\text { mniejsza dynamika } \\
\text { wzrostu zadłużenia }\end{array}$ \\
\hline $\begin{array}{c}\text { Współczynnik pokrycia zobowią- } \\
\text { zań nadwyżką finansową vs } \\
\text { wynik sportowy }\end{array}$ & $\mathrm{r}=0,460$ & $\begin{array}{c}\text { Umiarkowany, } \\
\text { dodatni }\end{array}$ & $\begin{array}{c}\text { Lepsze wyniki sportowe - } \\
\text { większa możliwość spła- } \\
\text { ty długu nadwyżką fi- } \\
\text { nansową }\end{array}$ \\
\hline $\begin{array}{c}\text { Współczynnik rentowności netto } \\
\text { vs wynik sportowy }\end{array}$ & $\mathrm{r}=0,408$ & $\begin{array}{c}\text { Umiarkowany, } \\
\text { dodatni }\end{array}$ & $\begin{array}{c}\text { Lepszy wynik sportowy - } \\
\text { większa rentowność net- } \\
\text { to sprzedaży }\end{array}$ \\
\hline $\begin{array}{c}\text { Wskaźnik dynamiki sprzedaży - } \\
\text { vs wynik sportowy }\end{array}$ & $\mathrm{r}=0,561$ & Znaczny, dodatni & $\begin{array}{c}\text { Lepszy wynik sportowy - } \\
\text { wzrost dynamiki przy- } \\
\text { chodów ze sprzedaży } \\
\text { netto }\end{array}$ \\
\hline
\end{tabular}

Źródło: opracowanie własne na podstawie badań giełdowych spółek akcyjnych. 
Interesujący może być również fakt, że umiarkowany stopień współzależności zanotowano w przypadku współczynnika rentowności netto wyliczonego dla klubów piłkarskich notowanych na Stoxx Europe Football Index, a osiaganymi przez nie rezultatami sportowymi (tab. 11). Współczynnik korelacji istniejących pomiędzy opisywanymi parametrami wyniósł $w$ badaniu $r=0,408$. Oznacza to, że uzyskiwane sukcesy sportowe w umiarkowanym względzie przekładają się na wzrost stopy marży zysku netto. Wyraźnie zarysowuje się jednak tendencja, że im lepsze wyniki sportowe dany klub osiągał, tym większe miał szanse na generowanie coraz to wyższego zysku na podstawowej, prowadzonej przez siebie działalności.

Na koniec należy podkreślić, iż zaobserwowano znaczny stopień współzależności pomiędzy wskaźnikiem dynamiki sprzedaży, a uzyskiwanymi przez kluby piłkarskie rezultatami sportowymi. Dość wysoka wartość współczynnika korelacji wynosząca $r=0,561$ świadczy o fakcie, iż osiąganie sukcesów sportowych z dużą dozą prawdopodobieństwa przyczynia się do generowania coraz to większych przychodów ze sprzedaży netto przez kluby piłkarskie. $Z$ drugiej zaś strony notowanie niesatysfakcjonujących wyników sportowych $\mathrm{w}$ znacznym stopniu powoduje spadek poziomu przychodów ze sprzedaży w porównaniu do roku poprzedniego.

\section{ZAKOŃCZENIE}

Hipoteza zakładająca, że standing finansowy klubów piłkarskich notowanych na Stoxx Europe Football Index w latach 2007-2011 jest w bardzo dużym stopniu uzależniony od osiaganego przez nie wyniku sportowego, została zweryfikowana negatywnie. W badaniach zauważono przeciętnie umiarkowane korelacje zachodzące między rozpatrywanymi miarami standingu finansowego, a uzyskiwanymi rezultatami sportowymi.

Zdaniem autora może to świadczyć o fakcie, że kluby piłkarskie - nawet te prosperujące $\mathrm{w}$ formie sportowych spółek akcyjnych - nie do końca powinny być postrzegane tylko i wyłącznie jako nowoczesne przedsiębiorstwa rynkowe. Są to także szeroko rozumiane ,instytucje społeczne”, z którymi utożsamia się liczne grono kibiców. Produktem przez nie oferowanym są zaś mecze piłkarskie, które mają stanowić dla klientów (kibiców) rozrywkę.

Oczywiście, sukcesy sportowe przekładają się w dużej mierze na możliwość uzyskania wyższych wpływów: od sponsorów, ze sprzedaży praw do transmisji telewizyjnych, za transfery piłkarzy itp. Fenomen nowoczesnych klubów piłkarskich polega jednak na fakcie, że część z nich może dobrze funkcjonować nawet bez spektakularnych sukcesów sportowych. Mają one bowiem rzeszę swoich stałych sympatyków, którzy wiernie kibicując zasilają klubową kasę poprzez zakup biletów, pamiątek klubowych itp. Uznane i popularne kluby piłkarskie, 
pomimo braku satysfakcjonujących wyników sportowych, w każdej chwili mogą też przyciagnąć bogatych biznesmenów, którzy zechcą zainwestować swój kapitał w piłkę nożną ${ }^{48}$. Nie dla zysku, lecz dla własnych satysfakcji, połączonych $\mathrm{z}$ działalnością pro publico bono.

\section{BIBLIOGRAFIA}

Biała Księga na Temat Sportu, Komisja Wspólnot Europejskich, Bruksela 2007.

B i eń W., Zarzadzanie finansami przedsiębiorstw, Difin, Warszawa 1991.

$\mathrm{Buhler}$ A., Football as an international business - an Anglo-German comparison, „European Journal for Sport and Society" 2006, Vol. 3(1), Plymouth 2006.

Dudek D., Pojęcie klubu sportowego, „Studia Humanistyczne” 2005, nr 5, Akademia Wychowania Fizycznego w Krakowie, Kraków 2005.

D u dek D., Krytyczne tezy do naukowych badań nad sportem, [w]: T. J u re k, K. Obod yń ski, S. Zaborniak (red.), Z dziejów turystyki i sportu w Polsce, Wydawnictwo Uniwersytetu Rzeszowskiego, Rzeszów 2009.

Dude k D., Zarys dziejów i organizacja stowarzyszeń kultury fizycznej, „Studia i Monografie” 2000, nr 16, Akademia Wychowania Fizycznego w Krakowie, Kraków 2000.

Ekstraklasa pitkarskiego biznesu 2011, Ernst \& Young, Warszawa 2011.

Głodowski M., Wycena klubu pitkarskiego na przykładzie Juventus Turyn, [w:] M. Panfil, A. Szablewski (red.), Wycena przedsiębiorstwa. Od teorii do praktyki, Wydawnictwo Poltex, Warszawa 2010.

Grudzew ski W., Hejduk I., Restrukturyzacja firmy jako kierunek wzrostu jej wartości, [w:] A. Herm an, A. S z a ble w s ki (red.), Zarzqdzanie wartościq firmy, Wydawnictwo Poltext, Warszawa 1999.

Hamil S., Michie J., O ught on C. (red.), A Game of Two Halves? The Business of Football, Edynburg 1999.

J a żd że w s k a I., Statystyka dla geografów, Wydawnictwo Uniwersytetu Łódzkiego, Łódź 2003.

Mak s y mi u k K., Cristiano Ronaldo w sprawozdaniu finansowym, czyli o wartościach niematerialnych w klubach pitkarskich, „BDO Podatki i Rachunkowość” 2008, nr 8(10), serwis internetowy www.bdo.pl.

M a r c in kow sk a M., Ocena działalności instytucji finansowych, Difin, Warszawa 2007.

Mosiądz M., Roy F., Klub sportowy a przedsiębiorstwo - podejście do wyceny, Fitz Roy Conculting \& Investments, serwis internetowy http://fitz-roy.pl/.

Rachunek satelitarny sportu dla Polski, Instytut Statystyki Publicznej Głównego Urzędu Statystycznego, Warszawa 2010.

Raport Calcio 2012, Federcalcio FIGC, Rzym 2012.

S koczylas W. (red.), Determinanty i modele wartości przedsiębiorstw, Polskie Wydawnictwo Ekonomiczne, Warszawa 2007.

Stownik Ekonomiczny PWN, serwis internetowy PWN Biznes www.biznes.pwn.pl.

Strategia rozwoju sportu w Polsce do roku 2015, Ministerstwo Sportu, Warszawa 2007.

Tacon R., Football and Social Inclusion: Evaluating Social Policy, Football Governance Research Center, Research Paper 2005 No. 1.

Tusiński Ł., Trzy podstawowe funkcje $w$ działalności klubów piłkarskich, serwis internetowy http://www.marketingsportowy.pl.

W a śn i e w s ki T., W. S k o c z y la s, Analiza finansowa w przedsiębiorstwie, WSB, Poznań 1997.

${ }^{48}$ Przykładem takiego postępowania w ostatnich latach mogą być drużyny takie jak: PSG,

Manchester City - które pomimo braku sukcesów sportowych zwróciły zainteresowanie arabskich szejków i praktycznie z dnia na dzień stały się jednymi z najbogatszych klubów piłkarskich w Europie. 


\section{Michat Comporek}

\section{SHAPING OF FINANCIAL STANDING OF FOOTBALL CLUBS LISTED ON THE STOXX EUROPE FOOTBALL INDEX IN YEARS 2007-2011 IN DEPENDS OF OBTAINED SPORTS RESULTS}

In contemporary world sport is a priceless civilizational, cultural and social value. In developed societies, it is seen as a common good, available in various forms - according to the abilities and interests of citizens. Sport is also a component of the social policy of the modern state, encouraging many sectors of the economy.

Analyzing the history of football, it appears that in most cases, football clubs have been established by the local communities in which they play, and so far played a very important role. However, many researchers are of the opinion that the currently functioning football clubs are similar to the typical manufacturing or service enterprises, aimed at generating profit.

The main goal of this article is to verify the hypothesis stating that ,the financial standing of football clubs listed on the Stoxx Europe Football Index in yeras 2007-2011 is much dependent on the result achieved by the sports". Hypothesis has been subjected to empirical verification using selected measures of assessing the effectiveness of the company's financial and statistical measures.

In the article shown legal recognition of sports clubs, nature of the valuation of their value or characteristics of the entities. Eventually an attempt was made to answer the question: whether desire of football clubs to reach as many sports success is solely motivated by financial premises?

Key words: financial standing, football clubs, sports results. 